\title{
Grapefruit: History, Use, and Breeding
}

\author{
Eliezer S. Louzada ${ }^{1}$ and Chandrika Ramadugu ${ }^{2}$
}

AdDiTIONAL INDEX WORDs. biotechnology, drug interaction, mutation breeding, natural mutation, protoplast, somatic hybrids

Summary. Grapefruit [Citrus ×aurantium (synonym C. $\times$ paradisi)] is an important citrus commodity that originated in Barbados in the 17th century. Grapefruit is the youngest member of the genus Citrus. Most commercially important grapefruit cultivars arose through natural and induced mutations, not traditional breeding, of the white-fleshed and seedy Duncan grapefruit. Now, cultivars with a range of flesh colors exist; the pigmentation is correlated with lycopene content. A bud sport mutant of grapefruit discovered in Texas has a deep golden-colored flesh, significantly different from the typical reddish pigmentation. In this review, we discuss grapefruit's journey from its origin in Barbados and its global establishment including production, marketing, drug interactions, cultivar development, genetic diversity, and commercially significant cultivars.

G rapefruit (Citrus $\times$ aurantium) belongs to the family Rutaceae, subfamily Aurantioideae. Grapefruit is unique among citrus (Citrus sp.) fruit due to its distinctive flavor, health benefits, and recent $\mathrm{Ca}$ ribbean islands' origin less than 300 years ago (Scora, 1975). Most cultivated citrus originated in Southeast Asia before 2000 BCE. Citron (Citrus med$i c a)$, considered a progenitor species of cultivated citrus (Raveh et al., 2020), dates back to 4000 BCE (Webber, 1967).

The origin of grapefruit in the Caribbean islands is shrouded in mystery and confusion (Kumamoto et al., 1987). Hughes (1750) reported a tree bearing the "forbidden fruit" in Barbados, but today's grapefruit is not a direct descendent of this tree. Browne (1756) also reported a tree bearing the "forbidden fruit" and associated it with 'Shaddock' pummelo

Received for publication 29 June. 2020. Accepted for publication 12 Mar. 2021

Published online 5 May 2021.

${ }^{1}$ Texas A\&M University Kingsville, Citrus Center, 312 N. International Blvd, Weslaco, TX 78599

${ }^{2}$ Department of Botany and Plant Sciences, University of California Riverside, 900 University Avenue, Riverside, CA 92521

We thank Melanie Schori of the U.S. Department of Agriculture, Agricultural Research Service, for help with the recent taxonomic names of citrus cultivars.

E.S.L. is the corresponding author. E-mail: Eliezer. louzada@tamuk.edu.

This is an open access article distributed under the CC BY-NC-ND license (https://creativecommons. org/licenses/by-nc-nd/4.0/).

https://doi.org/10.21273/HORTTECH04679-20
(Citrus maxima), describing it as a “smaller shaddock." Macfadyen (1830) classified the "forbidden fruit" reported by both Browne and Hughes as Citrus $\times$ paradisi also known as "barbados grapefruit." Bowman and Gmitter (1990) and Gmitter (1995) further confirmed the association of the now extinct "forbidden fruit" with 'Shaddock' pummelo and the present-day grapefruit. Based on chemotaxonomy (Scora et al., 1982) and molecular data (Wu et al., 2018), it is presumed that an accidental hybridization produced the interspecific hybrid of a pummelo and sweet orange $[C . \times$ aurantium var. sinensis (synonym $C . \times$ sinensis)], now classified as grapefruit. Earlier, grapefruit was considered an apomictically stabilized hybrid species (Kumamoto et al., 1987). However, taxonomists now characterize grapefruit as a set of cultivars rather than a species; it is classified as C. ×aurantium (M. Schori, personal communication).

This review discusses grapefruit's evolution from its identification in
Barbados to its development as an important agricultural commodity. We review the progress and fluctuations in production and market aspects. Because grapefruit is valued as a highly nutritious fruit, we will discuss the significant health benefits associated with it. Interaction of grapefruit with certain commonly used drugs has been reported; we examine the mode of interactions and address this concern.

The first commercial cultivation of grapefruit occurred less than 200 years ago. The original grapefruit tree produced very seedy fruit with white flesh; however, today, several different cultivars of nearly seedless fruit with a range of flesh coloration are available. We review the advances in grapefruit cultivar development, the efforts toward breeding novel, potentially desirable cultivars through conventional breeding, induction of mutations through irradiations, and other biotechnological approaches that may be useful for cultivar improvement. Finally, we describe the most important commercial grapefruit cultivars.

\section{Commercial importance and market history}

The United States leads The GRAPEFRUIT MARKET. Grapefruit was confined to the Caribbean islands for several hundred years. Zoller (1918) reported grapefruit flourishing in Mexico for decades before Count Odette Philippe brought grapefruit seeds to Florida in 1823, raised trees, and distributed seeds freely (Robinson, 1952). Regardless of the source of early grapefruit germplasm, it was in the United States that grapefruit first gained commercial importance. Initially there was confusion about grapefruit's nomenclature. Commercially it was known as grapefruit (Humes, 1909), and "pomelo" was a

\begin{tabular}{llll}
\hline $\begin{array}{l}\text { Units } \\
\text { To convert U.S. to SI, } \\
\text { multiply by }\end{array}$ & U.S. unit & SI unit & $\begin{array}{l}\text { To convert SI to U.S., } \\
\text { multiply by }\end{array}$ \\
\hline 0.4047 & acre(s) & $\mathrm{ha}$ & 2.4711 \\
4.1868 & calorie(s) & $\mathrm{kJ}$ & 0.2388 \\
3.7854 & gal & $\mathrm{L}$ & 0.2642 \\
2.54 & inch(es) & $\mathrm{cm}$ & 0.3937 \\
0.4536 & $\mathrm{lb}$ & $\mathrm{kg}$ & 2.2046 \\
28.3495 & $\mathrm{oz}$ & $\mathrm{g}$ & 0.0353 \\
$28,349,523$ & $\mathrm{Oz}$ & $\mu \mathrm{g}$ & $3.5274 \times 10^{-8}$ \\
28,350 & $\mathrm{Oz}$ & $\mathrm{mg}$ & $3.5274 \times 10^{-5}$ \\
1 & $\mathrm{ppm}$ & $\mu \mathrm{g} \cdot \mathrm{mL}^{-1}$ & 1 \\
0.9072 & $\mathrm{ton}(\mathrm{s})$ & $\mathrm{Mg}$ & 1.1023 \\
$\left({ }^{\circ} \mathrm{F}-32\right) \div 1.8$ & ${ }^{\circ} \mathrm{F}$ & ${ }^{\circ} \mathrm{C}$ & $\left({ }^{\circ} \mathrm{C} \times 1.8\right)+32$ \\
& & &
\end{tabular}

Hortlechnology $\cdot$ June $202131(3)$ 
synonym later discarded in favor of "grapefruit" (Merrill and Lee, 1924; Zoller, 1918). The first commercial shipments of grapefruit packed in barrels occurred from 1880 and 1885 from Florida to New York and Philadelphia. By 1889, grapefruit, though unfamiliar to most consumers, constituted $6 \%$ to $7 \%$ of Florida's citrus export (DePass, 1890). The great freeze of 1895 drastically reduced all citrus production in Florida (Humes, 1909), including grapefruit. By the 1909-10 season, the United States produced 44,760 tons of grapefruit with 98\% contribution from Florida [U.S. Department of Agriculture (USDA), 1945].

By 1915, Florida's production area consisted of 16,000 acres of bearing and 45,000 acres of nonbearing, 1- to 5-year-old grapefruit trees (Vaile, 1915). During the same period, the California industry had 600 acres of bearing and 1100 acres of nonbearing trees. The first commercial grapefruit orchards were planted in Texas in 1915 and produced 120 tons of fruit in the 1919-20 season (Vaile, 1915).

Grapefruit production increased substantially from 1919 to 1944, mainly in Florida and Texas. In Flori$\mathrm{da}$, in the 1919-20 season, the production was 236,000 tons; and by 1943-44, it surged to $1,240,000$ tons. In Texas, the production increased from 120 tons in the 1919-20 season to over 708,400 tons in the 1943-44 season. Arizona production increased from 870 tons in the 1919-20 season to 122,400 tons in 1943-44; California production surged from 570 to 99,000 tons for the same period (USDA, 1945). The escalation of grapefruit production between 1910 and 1940 in the United States was significant; over 3000\% compared with the $300 \%$ increase in sweet orange production (McLeaish, 1939).

The Texas grapefruit industry was confined to the southernmost part of the state, where it flourished. By 1937, Texas's 6300 producers accounted for $25 \%$ of the grapefruit growers producing $24 \%$ of the nation's fruit, second only to Florida's 64\%. Per capita consumption of grapefruit in the United States was 5.7 fruit between 1923-27, increasing to 7.5 fruit between 1931-35 (Goenig, 1937). The increased popularity was attributed to the processing industry that commercialized canned juice, juice concentrate, marmalade, wine additives, and candied peel. From 1932 to 1937, grapefruit processing in Florida's 50 canneries increased from 80,000 to 420,000 tons of grapefruit annually. By 1936, Texas had 30 canneries (Heid, 1937 ) that processed 260,000 tons of grapefruit (about 157 million cans of juice) in the 1939-40 season, generating $\$ 7$ million (Watson, 1940a, 1940b). By 1946, the U.S. production increased to 2,521,200 tons, of which Florida contributed 1,280,000 tons and Texas 920,000 tons (TexSun News, 1948).

United States' grapefruit acreage increased from 28,800 acres in 1919 to 198,500 acres in 1947 as new production areas were developed (Fig. 1). Freezes in 1951, 1962, 1985, and 1989 intermittently reduced both bearing area and production. A look at variation in the planting area when freezes occurred shows that the reduction in acreage was significant in Texas [data shown for 10-year blocks (Table 1)]. The other states did not have such drastic effects; in some regions, the planting areas increased after the freeze. In Feb. 2021, grapefruit groves in Texas were hit with a severe freeze, with some groves showing a temperature of $-7.2^{\circ} \mathrm{C}$ for several hours; damages are still being evaluated (E.S. Louzada, unpublished data). During the years with most severe freezes, the production values were brought to zero or to less than 10,000 tons in Texas. In 2000, the devastating bacterial disease citrus canker (caused by Xanthomonas citri ssp. citri) was reintroduced to Florida, precipitating an eradication program that lasted until 2006. About 1.56 million commercial trees and 600,000 dooryard trees were removed (Graham et al., 2004; Zansler et al., 2005). In 2005, the bacterial disease citrus greening or huanglongbing (HLB), associated with Candidatus Liberibacter asiaticus (CLas) and vectored by asian citrus psyllid (Diaphorina citri), was reported in Florida (Halbert, 2005). The effect of HLB in Florida has been significant, and the disease has destroyed many citrus groves. The two major diseases in Florida, citrus canker and HLB, along with the seasonal hurricanes, have resulted in a drastic reduction of U.S. grapefruit-bearing areas to about 46,400 acres, equivalent to the
1922-23 season. Most of the decrease in U.S. grapefruit-bearing area occurred in Florida; production in the 1999-2000 season was 2,270,000 tons, harvested from 114,100 acres and declined to 180,400 tons from 24,700 acres in the 2018-19 season. Acreage in Florida in 2020 reduced to 21,700 acres (USDA, 2020a).

HLB was first reported from Texas in 2012 (Kunta et al., 2012), but no significant reduction in fruit production has been reported after 8 years of disease establishment. In the1999-2000 season, grapefruit production in Texas was 237,000 tons from 20,000 acres; in the 2018-19 season, the yield was 244,000 tons from 16,000 acres. The reduction of acreage in Texas occurred because of freezes, other citrus diseases caused by soil-borne pathogens such as Phytophthora nicotianae, and urbanization.

In California, HLB was first reported from a citrus plant in a residential area in 2012 (Civerolo, 2015); the disease was restricted to backyard citrus for 8 years. In 2020, a CLas-positive asian citrus psyllid was reported from a commercial grove in southern California (Citrus Industry News, 2020), indicating disease spread.

California's total grapefruit production was 241,000 tons from 16,600 acres in the 1999-2000 season and reduced to 128,000 tons from 9000 acres in 2018-19 and to 87,000 tons in the 2019-20 season. When an exotic disease like HLB establishes, there is sustained yield decline, and the affected groves may never recover. Unless a permanent solution is found for HLB, it will be challenging to restore citrus yields to the levels reported before disease establishment. It is also important to note that hurricanes, like freezes, had a temporary, seasonal effect on the Florida grapefruit production. Although yield was reduced by hurricanes, the bearing area was unaffected. In Florida, the hurricanes exacerbated the spread of citrus canker and indirectly affected citrus yield.

GRAPEFRUIT MARKET IN OTHER COUNTRIES. While the grapefruit industry was booming in the United States, it was developing slowly in other citrus-growing regions of the world. In the Caribbean islands where grapefruit originated, the industry was not successful due to various factors. In 1929, C. Powel 


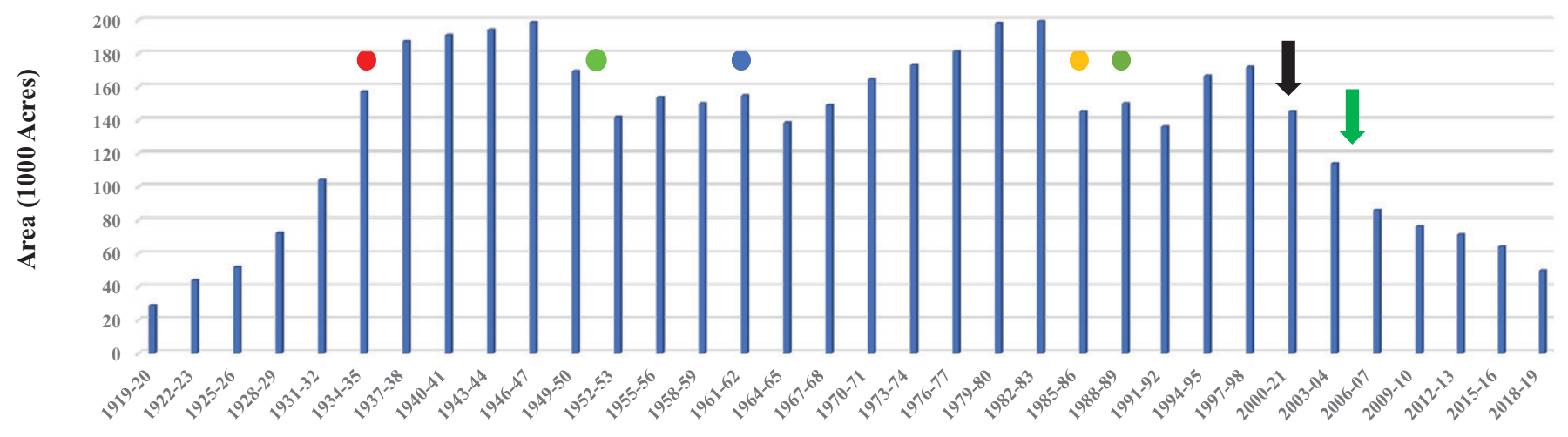

Crop Season

Freeze $1934 \bigcirc$ Freeze $1951 \bigcirc$ Freeze $1962 \bigcirc$ Freeze $1985 \bigcirc$ Freeze 1989 Citrus Canker Eradication HLB detected in Florida

Fig. 1. Evolution of grapefruit bearing area in the United States from 1919 to 2020 (Freie, 1987; Shuler and Scarborough, 1963; U.S. Department of Agriculture, 1950, 1960, 1973, 1981, 2000, 2017b, 2020c); HLB = citrus huanglongbing, 1 acre $=0.4047$ ha.

summarized the reasons to the West Indies Committee in London, as follows: the Jamaican and Bahamian grapefruit sectors were small, with untrained peasants managing from 2 - to 5-acre groves that produced modest quantity of poor-quality fruit. In Grenada, the prime agricultural land was devoted to the cultivation of nutmeg (Myristica fragrans) and cocoa (Theobroma cacao). The 200 to 300 acres of land designated for grapefruit cultivation in Saint Lucia was poorly managed. The 400 acres of grapefruit planted in Trinidad was not adequate to establish a thriving industry (Powell, 1929).

By 1929, the world grapefruit production reached 392,000 tons. The United States and Puerto Rico contributed 372,000 tons, Cuba 8000 tons, Jamaica 4000 tons, South Africa 4000 tons, and other countries 4000 tons (Tutt, 1929). Palestine developed a strong grapefruit industry, with a dramatic production increase from 4240 tons in 1930 to 80,000 tons in 1940 , becoming a vital grapefruit exporter primarily to European countries (Watson, 1940a, 1940b). The global grapefruit market expanded steadily from 1950 to 2020, with China producing 4.9 million tons in 2019-20, more than 10 times the 485,000 tons produced in the United States. However, the Chinese production also includes pummelo. South Africa is currently in third place with 387,000 tons and Mexico in fourth with 350,000 tons. Turkey produced 270,000 tons, Israel 155,000 tons, European Union 96,000 tons, and others contributed 26,000 tons (USDA, $2020 \mathrm{~b}$ ). Grapefruit is now produced in almost all citrus-producing countries with 6.7 million tons produced in the 2019-20 season (USDA, 2020b). In about a decade (2004-13), the global grapefruit production increased $45 \%$, generating market revenue of $\$ 6.5$ billion in 2015 (IndexBox Marketing Association, 2017; USDA, 2017a).

\section{General benefits and nutritional value of grapefruit}

Citrus fruit is nutrient-dense with vitamins, folate, phytochemicals like flavonoids, carotenoids, coumarins, terpenes, and limonoids (Rampersaud, 2007; Zhang, 2007). Grapefruit is recognized as a functional food, valued in certain cultures as promoting health due to the flavonoid compounds present in the fresh fruit and the juice (Kiani and Imam, 2007; Tundis et al., 2014; Yu et al., 2005; Zou et al., 2016). Table 2 shows nutritional information from one-half of a medium-sized grapefruit (123 g). Recognized as a low-energy-dense food (in calories per gram), it has omega- 3 and omega- 6 fatty acids, 18 of the 20 amino acids, is rich in glutamic and aspartic acids, arginine, proline, and phenylalanine. It is abundant in vitamins, with over 1400 international units (IU) of vitamin A, high in alpha and beta-carotene, lycopene, vitamin $\mathrm{C}$, in addition to multiples of bioactive compounds. Grapefruit is moderately rich in potassium, with $166 \mathrm{mg}$ per half-portion of a medium-sized fruit (University of Michigan, 2016). Consumption of half a grapefruit supplies complex nutrients essential to a healthy diet; some consider it an antiobesity ingredient. Public awareness of these health benefits has increased fruit and juice consumption, and demand in many countries.

FlavonoIDs. Flavonoids are lowmolecular-weight phenolic compounds with known antioxidant activity (Codoñer-Franch and Valls-Belles, 2010; Liu, 2004). Flavonoids consist of two benzene rings and an oxygenated heterocycle pyrone ring. Six dietary flavonoids are recognized: flavones, flavonols, flavanones, flavanols (catechins), anthocyanins, and isoflavonoids (Zhang, 2007). Citrus has four types of the flavonoids: flavanones (about $98 \%$ ), and smaller amounts of flavones, flavonols, and anthocyanins (Benavente-Garcia et al., 1997). Naringin, the major flavanone in grapefruit (together with hesperidin and rutin) alter lipid and glucose metabolism and improve hyperlipidemia and hyperglycemia in animal models with type 2 diabetes (Da Silva et al., 2001; Jung et al., 2006). Flavonoids are also reported to have anti-ischemic, antioxidant, vasorelaxant, and antithrombotic properties (Mink et al., 2007; Pan et al., 2010). The antioxidant and free-radical scavenging nature of flavonoids mitigate vitamin C oxidation (Mink et al., 2007). Naringin decreases the risk of atherosclerosis, reduces radiation-induced chromosome damage, and stimulates DNA repair in cancer cells ( $\mathrm{Li}$ et al., 2013; Zhang, 
Table 1. Effect of major freezes on grapefruit acreage in the United States.

\begin{tabular}{|c|c|c|c|c|}
\hline \multirow[b]{2}{*}{ Season } & Florida & Texas & California & Arizona \\
\hline & \multicolumn{4}{|c|}{ Area $(1000 \text { acres })^{\mathrm{z}}$} \\
\hline $1945-46$ & 85.2 & 78.6 & 14.5 & 12.9 \\
\hline $1946-47$ & 85.7 & 80.0 & 14.1 & 12.9 \\
\hline $1947-48$ & 87.6 & 80.5 & 13.3 & 12.2 \\
\hline $1948-40$ & 89.5 & 82.0 & 11.6 & 10.3 \\
\hline $1949-50$ & 93.0 & 56.0 & 10.7 & 9.6 \\
\hline $1950-51$ & 94.4 & 56.0 & 10.2 & 9.4 \\
\hline $1951-52^{y}$ & 98.6 & $17.9^{x}$ & 9.7 & 9.4 \\
\hline $1952-53$ & 102.0 & 20.9 & 9.4 & 9.4 \\
\hline $1953-54$ & 105.0 & 22.0 & 9.1 & 7.9 \\
\hline $1954-55$ & 111.0 & 24.1 & 8.2 & 7.9 \\
\hline $1961-62$ & 94.0 & 45.3 & 9.5 & 5.6 \\
\hline $1962-63^{y}$ & 88.0 & $35.0^{\mathrm{x}}$ & 10.9 & 6.0 \\
\hline $1963-64$ & 83.0 & 36.0 & 11.9 & 6.0 \\
\hline $1964-65$ & 84.0 & 36.0 & 12.3 & 6.1 \\
\hline $1965-66$ & 85.8 & 37.0 & 12.6 & 6.7 \\
\hline $1966-67$ & 87.0 & 39.0 & 12.8 & 6.9 \\
\hline $1967-68$ & 87.5 & 41.0 & 12.8 & 7.6 \\
\hline 1968-69 & 90.3 & 45.0 & 12.7 & 4.9 \\
\hline 1969-70 & 98.7 & 40.0 & 12.8 & 6.1 \\
\hline $1970-71$ & 107.2 & 37.0 & 12.1 & 6.3 \\
\hline 1983-84 & 119.6 & 43.3 & 21.9 & 6.8 \\
\hline $1984-85^{y}$ & 115.5 & $19.1^{\mathrm{w}}$ & 21.1 & 7.1 \\
\hline $1985-86$ & 105.1 & $13.5^{x}$ & 20.9 & 5.7 \\
\hline $1986-87$ & 106.0 & 15.2 & 20.8 & 5.9 \\
\hline $1987-88$ & 106.0 & 16.0 & 20.7 & 6.0 \\
\hline 1988-89 & 106.9 & 16.9 & 19.9 & 6.5 \\
\hline $1989-90^{y}$ & 103.0 & 18.7 & 19.2 & 6.4 \\
\hline 1990-91 & 104.2 & $4.5^{\mathrm{w}}$ & 18.3 & 6.2 \\
\hline 1991-92 & 104.7 & $7.7^{\mathrm{x}}$ & 18.5 & 5.9 \\
\hline 1992-93 & 111.9 & 10.1 & 17.8 & 5.9 \\
\hline
\end{tabular}

\footnotetext{
${ }^{\mathrm{z}} 1$ acre $=0.4047$ ha.

${ }^{\mathrm{y}}$ Freezes.

${ }^{\mathrm{x}}$ Production below 10,000 tons $(9071.8 \mathrm{Mg})$.
}

${ }^{\mathrm{w}}$ Zero production.

2007). Naringenin, the aglycone form of naringin, is demonstrated to be among the more active naringins (Kiani and Imam, 2007).

CARotenoids. The primary carotenoids in grapefruit are lycopene and $\beta$-carotene. Lycopene is a fat-soluble tetraterpene, a powerful antioxidant known to prevent heart disease, cancer, and macular degeneration. The yellow, orange, and red pigmentation of grapefruit is dependent on the ratios of lycopene, $\beta$-carotene, trace amounts of phytofluene, zeaxanthine, $\beta$-cryptoxanthine, and zeta carotene (Curl and Bailey, 2006; Zhang et al., 2016). White-fleshed grapefruit cultivars also have trace amounts of lycopene (Cameron et al., 1964) and a significant $\beta$-carotene content. The red Marsh grapefruit mutants have 790 -fold higher carotenoid content than the white- fleshed parent cultivar (Xu et al., 2006); 'Ruby Red' has about $1745 \mu \mathrm{g}$ of lycopene in a half fruit (Table 2).

The health benefits of lycopenerich foods are numerous. Lycopene from grapefruit and tomato (Solanum lycopersicum) inhibited an aggressive form of prostate cancer in rats (Rattus rattus) (Giovannucci, 2005; Gunasekera et al., 2007). In pancreatic cancer patients, cancerous lesions decreased when lycopene was incorporated into the diet (Kucuk et al., 2001). Lycopene reduced liver cancer in rats (Agca et al., 2012) and oral and breast cancer in humans (Gupta et al., 2015; Sato et al., 2002). The antiplatelet and antiapoptotic effects of lycopene reduce arterial stiffness (Mozos et al., 2018), making it an effective antiatherosclerotic, antioxidant, anti-inflammatory, and antihypertensive agent able to lower the incidence of myocardial infarctions (Kohlmeier et al., 1997). Lycopene treatment of ovariectomized rats suppressed bone turnover and restored bone strength (Ardawi et al., 2016). In epileptic mice (Mus musculus), lycopene reversed oxidative damage, demonstrating neuroprotective potential (Bharadwaj and Kumar, 2016). In studying Alzheimer's disease using cultured human cell and nematode system (Caenorhabditis elegans), lycopene delayed paralysis, protected against hydrogen peroxide-induced oxidative stress, and decreased pathogenesis (Chen et al., 2015). Lycopene has been demonstrated to ameliorate neuropathic pain (Zhang et al., 2016), and it is an effective prophylactic for cataracts in rat model systems (Gupta et al., 2003). Lycopene dietary supplements have been reported as decreasing oxidative stress and improving bone metabolism. Analysis of data from human clinical trials indicated that while lycopene supplements are effective in certain situations, consumption of whole foods containing lycopene significantly promotes cardiovascular health (BurtonFreeman and Sesso, 2014; Caseiro et al., 2020).

Furanocoumarins. Furanocoumarins are secondary metabolites that defend plants against insects and pathogens. They are polyphenolic compounds consisting of a furan ring fused with coumarin. These compounds are associated with antioxidative, anti-inflammatory, and bone health-promoting properties in human subjects. In western societies, about $73 \%$ of the dietary furanocoumarins are obtained through grapefruit consumption (Hung et al., 2017). The major furanocoumarins present in grapefruit are bergamottin, epoxybergamottin, and 6', 7'-dihydroxybergamottin (DHB). The furanocoumarin content in grapefruit juice can vary based on the flesh coloration (red, pink, or white), the fruit's maturity level, fruit part, juice processing technique, and storage conditions. The health benefits of furanocoumarins are well documented in the literature (Chudnovskiy et al., 2014; Madrigal-Bujaidar et al., 2013; Mahgoub, 2002; Wang and Reuss, 2018). Bergamottin inhibits cancer cell growth and suppresses fibrosarcoma metastasis in humans (Ko et al., 2018). Furanocoumarins are also known to influence bone health. Bergapten has antiosteoporosis activity demonstrated by 
in vitro and in vivo experiments (Hung et al., 2017).

\section{Drug interactions}

Grapefruit juice is known to interact with several commonly administered prescription medications. The first drug interaction was reported in 1989; Bailey et al. observed that the concentrations of felodipine, a calcium channel blocker, were elevated in a patient's blood plasma after grapefruit consumption (Bailey et al., 1989). According to current reports, pharmacological activity of 85 prescription drugs is affected if grapefruit is consumed with an oral medication with low-to-medium bioavailability (Bailey et al., 2013). The drug interactions are caused by the disruption of the enteric cytochrome P4503A4 enzyme (CYP3A4) activity. Under normal conditions, the drugs are metabolized in the small intestine by CYP3A4 before the system absorbs them. The furanocoumarins bergamottin and DHB inhibit CYP3A4 activity in the gastrointestinal tract, resulting in reduced intestinal metabolism of the drugs (Owira and Ojewole, 2010). Because the drug's pre-systemic degradation is decreased, bioavailability and absorption are increased, resulting in drug overdoses.

SPECIFIC INTERACTIONS. Several types of drugs are affected by the furanocoumarin-induced process in the intestines. Commonly used medications that show altered activity when consumed with grapefruit juice include HMG-CoA reductase inhibitors prescribed for lowering cholesterol (atorvastatin, simvastatin, lovastatin), calcium channel blockers prescribed for blood pressure regulation (felodipine, nifedipine), certain antihistamines (fexofenadine), immunosuppressants (cyclosporine, tacrolimus), pain medications (methadone), and some psychiatric drugs (buspirone, triazolam, diazepam, midazolam, sertraline). Grapefruit and its processed products are contraindicated when these drugs are administered (Hanley et al., 2011).

Overdoses of antilipemic drugs such as statins can be toxic at excessive systemic concentrations and potentially lead to rhabdomyolysis; skeletal muscle damage caused by excessive myoglobin release into the blood results in renal failure (Lilja et al., 1998b). Cyclosporine and tacrolimus are administered for preventing organ rejection after liver transplants; furanocoumarin interactions can cause drug overdose leading to nephrotoxicity (Ducharme et al., 1995). Increased concentrations of several anticancer agents in the system can result in a situation called "torsade de pointes." In this condition, the patient may develop abnormal heart rhythm leading to sudden cardiac death (Libersa et al., 2000). Table 3 has a list of common drugs that are known to cause furanocoumarin-induced pharmacokinetic changes.

ALLEVIATING THE PROBLEM OF DRUG INTERACTION ASSOCIATED WITH GRAPEFRUIT CONSUMPTION. A better understanding of the interactions between grapefruit furanocoumarins and oral drugs in the human alimentary canal is needed. Speculations based on in vitro experiments and studies conducted with model animals are not always clinically relevant. Alternative medications that are unaffected by grapefruit juice consumption are valid options. Activity of certain antilipemic statins such as fluvastatin, pravastatin, and rosuvastatin are unaffected by simultaneous consumption of grapefruit juice. Fluvastatin and rosuvastatin are metabolized in the liver by a different enzyme, CYP2C9, that does not interact with furanocoumarins; pravastatin is metabolized in the liver, and hence the bioavailability is unaffected by consumption of grapefruit (Owira and Ojewole, 2010). Because of the significant health benefits of grapefruit consumption, it is unreasonable to completely avoid grapefruit products (Mertens-Talcott et al., 2006). Recently generated grapefruit hybrids with low concentrations of furanocoumarins, such as ' 914 ', 'Aliza', and 'Cookie', may be used for patients desiring to obtain nutritional benefits from grapefruit in their diet ( $\mathrm{Fi}-$ del et al., 2016; Gmitter, 2014).

Table 2. Nutritional information of $1 / 2$ grapefruit $[2-3 / 4$ inches $(7.0 \mathrm{~cm})$ diameter, $123 \mathrm{~g}(4.34 \mathrm{oz})$, with pink or red flesh] (Nutrition Data, 2020).

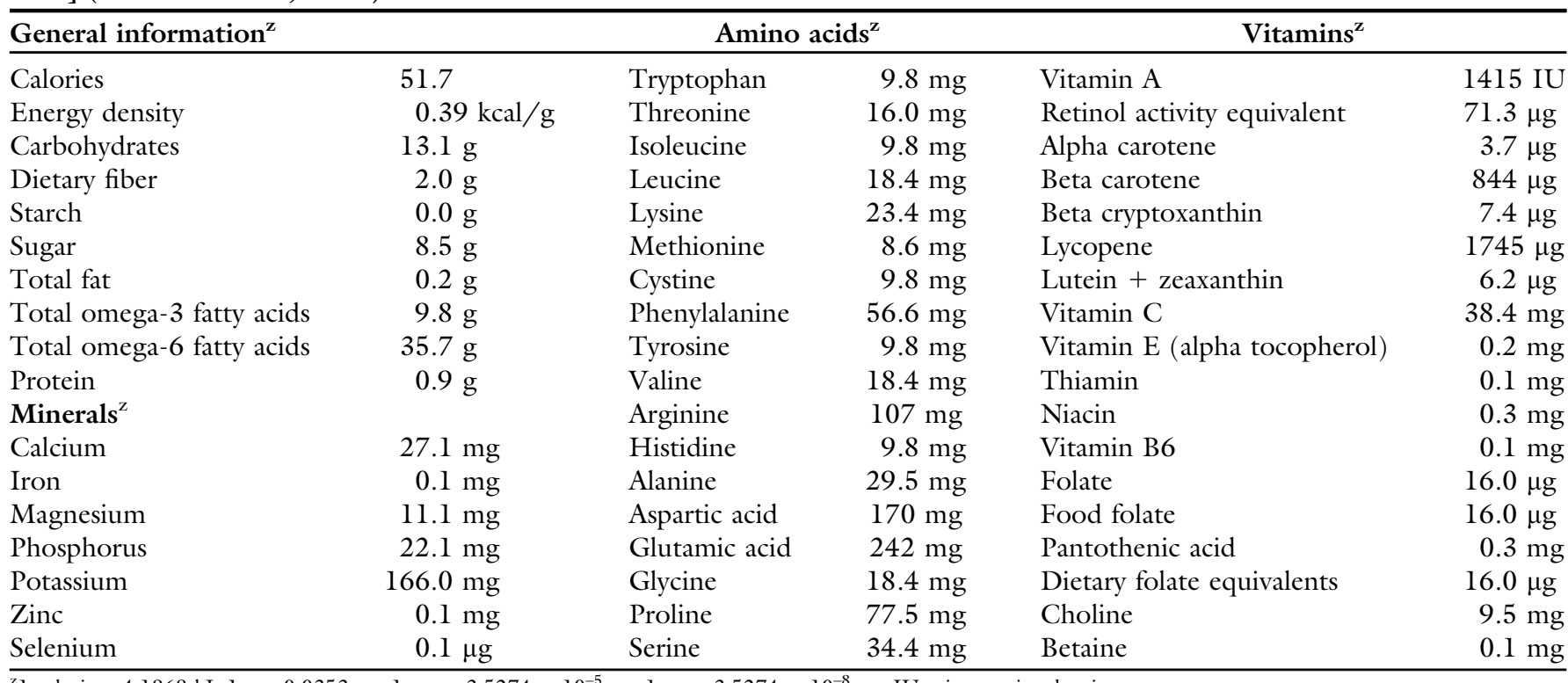

${ }^{\mathrm{z}} \mathrm{l}$ calorie $=4.1868 \mathrm{~kJ}, \mathrm{l} \mathrm{g}=0.0353 \mathrm{oz}, \mathrm{l} \mathrm{mg}=3.5274 \times 10^{-5} \mathrm{oz}, \mathrm{l} \mu \mathrm{g}=3.5274 \times 10^{-8} \mathrm{oz}$, IU $=$ international units. 
Processing to reduce the active ingredient involved in drug interactions of grapefruit offers potential solution (Girennavar et al., 2008). Furanocoumarin concentration in extracted grapefruit juice is affected by the processing conditions. Use of MA packaging (that uses materials and formats with an appropriate level of gas barrier) reduces the concentration of furanocoumarins (Hung et al., 2017). Pasteurization of juice at $60^{\circ} \mathrm{C}$ for 60 min reduced levels of bergamottin and DHB (Cancalon et al., 2011). Grapefruit juice treated with adsorption resins to remove furanocoumarins did not increase the drug felodipine's systemic bioavailability in human volunteers (Paine et al., 2006). Treating grapefruit juice with heat or ultraviolet light significantly reduced undesirable pharmacokinetic interactions (Uesawa and Mohri, 2006a, 2006b).

Grapefruit consumption is a concern in vulnerable elderly patients on multiple medications (Bressier and Bahl, 2003). In patients with liver cirrhosis, CYP3A4 activity is crucial (Kiani and Imam, 2007). Rhabdomyolosis from an overdose of cholesterol-reducing statins occurs in about four per 100,000 people per year (Lee et al., 2016). Drug interaction studies using model organisms are often based on administering high volumes of grapefruit juice or related products [i.e., 1-1.5 L juice per day, $1.5 \mathrm{~kg}$ marmalade per week (Bailey et al., 2013)]. Such studies often misrepresent the dietary intake of patients under normal conditions. Lee et al. (2016) discuss the low risk of rhabdomyolysis associated with statins consumed with grapefruit. The phytochemicals in grapefruit confer cardiovascular benefits that often outweigh the associated risks caused by drug interactions. Selecting alternate drugs may allow incorporating moderate amounts of grapefruit in the diet. It is prudent to consider the net health benefits before contraindicating grapefruit consumption (Lee et al., 2016; Paine et al., 2006).

IMPROVING COMMERCIAL ACCEPTABILITY OF GRAPEFRUIT. In addition to reducing the negative interactions of grapefruit with certain prescription drugs, reducing bitterness would enhance consumer approval of grapefruit. While bitterness is an accepted characteristic, it is often cited as a reason for disliking grapefruit (Obenland et al., 2018). The flavonoid naringin $[4$ ', 5,7 -trihydroxyflavanone-7- $\beta$-L-rhamnoglucoside-( 1,2$)-\alpha$-D-glucopyranoside] and the limonoid limonin (7,16-dioxo-7,16-dideoxylimondiol) produce the bitterness. If the naringin concentration is higher than 300-400 $\mu \mathrm{g} \cdot \mathrm{mL}^{-1}$, grapefruit juice is considered bitter (Soares and Hotchkiss, 1998). Grapefruit sweetness, measured by the hedonic score (indicating acceptable sensory quality) increases with the sugar content. In a study of four grapefruit cultivars, Obenland et al. (2018) noted that the bitterness perceived by a trained sensory panel correlated negatively with the hedonic score (Obenland et al., 2018). Bitterness varies with cultivar type, maturity, and juicing methods. Juice extracted from the whole fruit will have a higher flavonoid concentration because flavonones are significantly higher in the segment membrane and peel (Rouseff et al., 1987). Grapefruit juice can be "debittered" through adsorption and enzymatic hydrolysis by naringinase (Chien et al., 2001).

\section{Grapefruit breeding}

Grapefruit cultivars have a narrow genetic base; hybridization to increase genetic diversity is desirable. Commercially significant grapefruit market cultivars did not originate through conventional breeding. Many of these can be traced back to a series of natural budsports or induced mutations of the original white grapefruit that produced cultivars with flesh colors ranging from white to pinkish, peach, and red (Fig. 2). A deep-golden-fleshed grapefruit (Fig. 3) discovered in Texas is presumed to be a somatic mutant of a white grapefruit resembling 'Duncan' (E.S. Louzada, unpublished data). A grapefruit family tree, depicting cultivars that originated by spontaneous bud sports, induced mutations, and by sexual crosses (leading to grapefruit-like cultivars), is shown in Fig. 4.

LIMITATIONS TO SEXUAL BREEDING. Like most citrus, grapefruit has a high degree of sporophytic apomixis leading to polyembryony; multiple genetically identical embryos develop from a single fertilized egg cell by natural embryogenesis of cells from the walls of the embryo sac (Kotlunow et al., 1996) (Fig. 5 ). These vigorous multiple embryos are clones of the mother plant. When grapefruit is used as the seed parent in breeding, the zygotic hybrid embryos resulting from sexual reproduction generally do not develop due to fierce competition from the numerous, robust nucellar embryos. It is challenging to create a sufficiently large hybrid population for the selection of superior cultivars by embryo rescue methods because the weaker zygotic embryos are eliminated due to lack of nourishment. Because citrus is a perennial crop with a long juvenility period, generating improved cultivars through traditional breeding is time-consuming. Field trials for new cultivar evaluations require considerable land and resources. $\mathrm{Nu}-$ cellar embryony and economic considerations are the predominant factors limiting the availability of new grapefruit hybrids.

Nucellar embryony played significant role in the serendipitous origin of grapefruit in Barbados. The English settlers on Barbados Island, not familiar with the asexual propagation commonly practiced for citrus, cultivated 'Shaddock' pummelo from seed. The self-incompatible 'Shaddock' presumably outcrossed with a sweet orange resulting in a hybrid with apomictic traits inherited from the sweet orange pollen parent. Repeated propagation from the seeds that generated "true-totype" progeny probably led to the multiplication of grapefruit trees that later stabilized as an apomictic species (Kumamoto et al., 1987).

SeXual BReeding. Tangelos [ $C$. $\times$ aurantium (synonym $C . \times$ tangelo)] are the oldest known grapefruit hybrids that resulted from a planned breeding program. These mandarinlike hybrids were generated from a cross of the 'Dancy' mandarin (Citrus reticulata) seed parent with the 'Duncan' grapefruit pollen parent. Three well-known tangelos are 'Orlando', 'Minneola', and 'Seminole' (Hodgson, 1967). Recently, a grapefruit-like hybrid named 'Dany' was produced by a cross of 'Michal' mandarin with 'Duncan' grapefruit (Fidel et al., 2016). A cross of 'Pearl' tangelo with a 'Marsh' or 'Duncan' grapefruit produced a hybrid with a low amount of volatiles and a milder juice than 'Marsh' (Shaw et al., 2001). 
Table 3. Medications known to interact with furanocoumarins in grapefruit products.

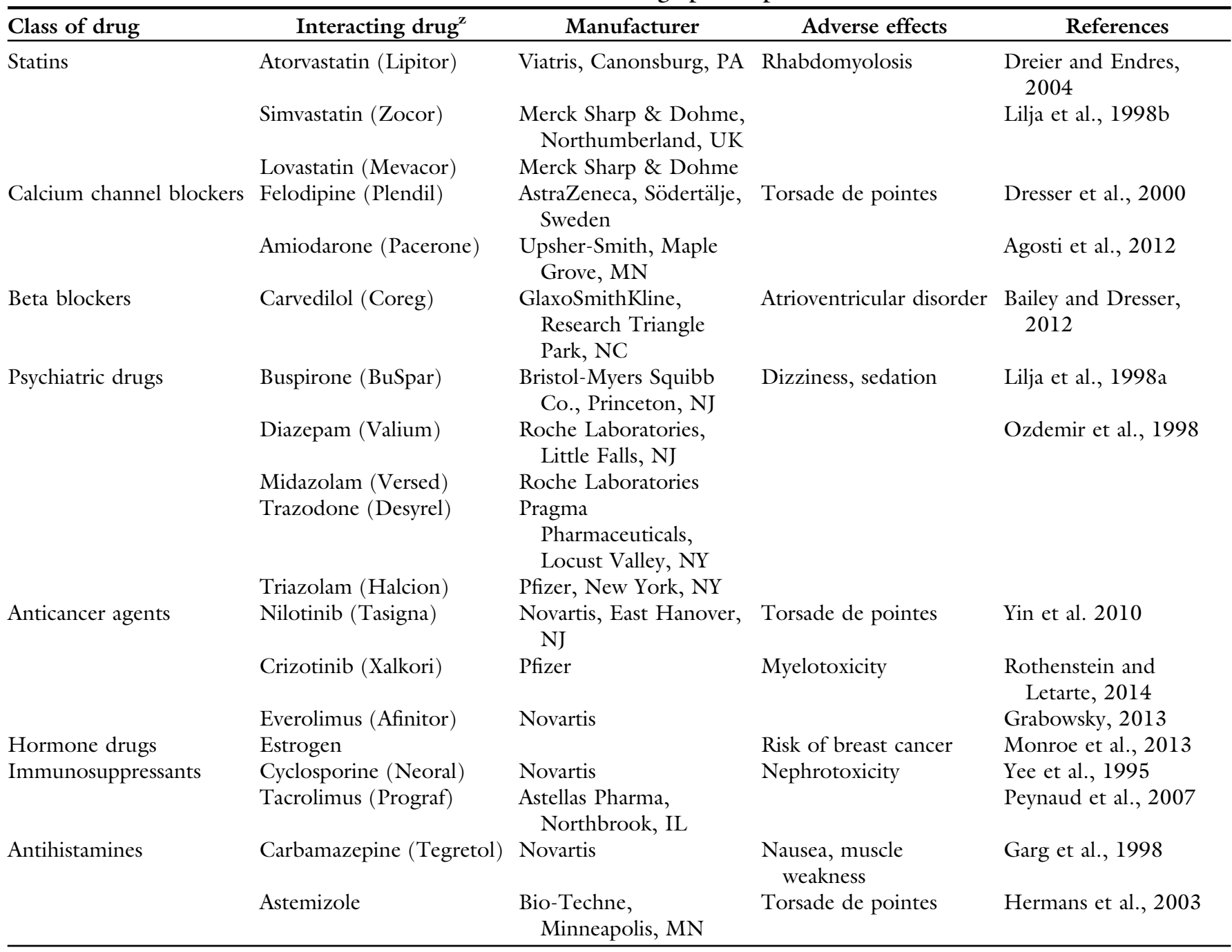

${ }^{\mathrm{z}}$ Representative drug with trade name in parentheses.

The two most prominent grapefruit hybrid cultivars to date are Oroblanco (Soost and Cameron, 1980) and Melogold (Soost and Cameron, 1986). Both cultivars are triploid and seedless, resulting from a cross between a diploid (2n) lowacid pummelo with a tetraploid (4n) white Marsh grapefruit. A red 'Oroblanco'-like grapefruit, named 'Einat', was recently reported from a cross of a tetraploid 'Hudson' grapefruit with a diploid low-acid pummelo (Fidel et al., 2016). Another red-fleshed grapefruit, also produced by a cross of a diploid low-acid pummelo with a tetraploid 'Ruby Red' grapefruit, was patented under the name '914' (Gmitter, 2014). The hybrid cultivar 914 has an extremely low furanocoumarin content, making it safe for people taking medications that interact with furanocoumarins (Nature Biotechnology, 2013). Tetraploid citrus plants have been useful to produce seedless triploid offspring by interploid crosses.

Toolapong et al. (1996) produced 51 triploid grapefruit hybrids by $2 n \times 2 n$ cross of 'Banpeiyu' pummelo with 'Ruby Red' grapefruit. Crosses of sweet orange or mandarin with pummelo generate novel citrus types with grapefruit characteristics. A grapefruit-like hybrid was produced by crossing the seed parent 'Nakon' pummelo with the 'Shamouti' sweet orange (Shaw et al., 2001). When mandarin cultivars Orah and Frua were crossed with Chandler and Siamese Sweet pummelo, respectively, two grapefruit-like hybrids (Aliza and Cookie) were produced. These two hybrids have only traces of furanocoumarins (Fidel et al., 2016), and, therefore, are expected to have less interaction with prescription drugs.

Except for 'Melogold' and 'Oroblanco', the grapefruit hybrids developed are not yet commercially available. The 'New Zealand' grapefruit, assumed to be a pummelo hybrid, is commercially important in New Zealand (Hodgson, 1967). Figure 4 shows a detailed grapefruit family tree.

MUTATION BREEDING. Mutation has been a significant source of genetic variation in all citrus species. Natural or induced mutations have produced most of the commercial cultivars of sweet orange or grapefruit. The mandarin group is more amenable to conventional breeding because many cultivars are monoembryonic. 


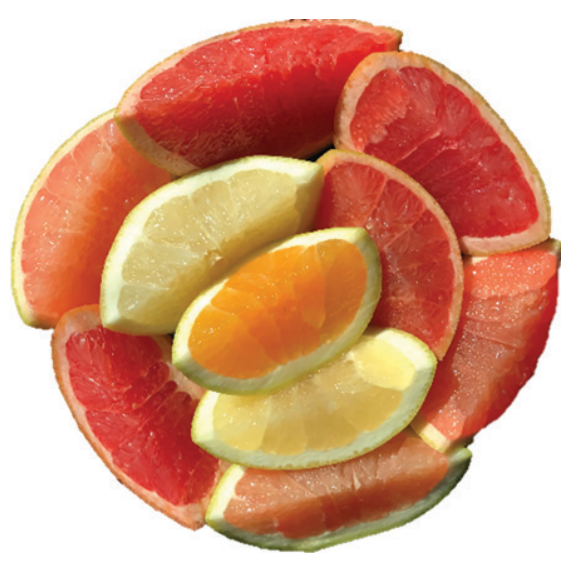

Fig. 2. Slices of grapefruit showing flesh pigmentation ranging from white to various shades of red and a new cultivar of grapefruit with goldencolored flesh is shown.

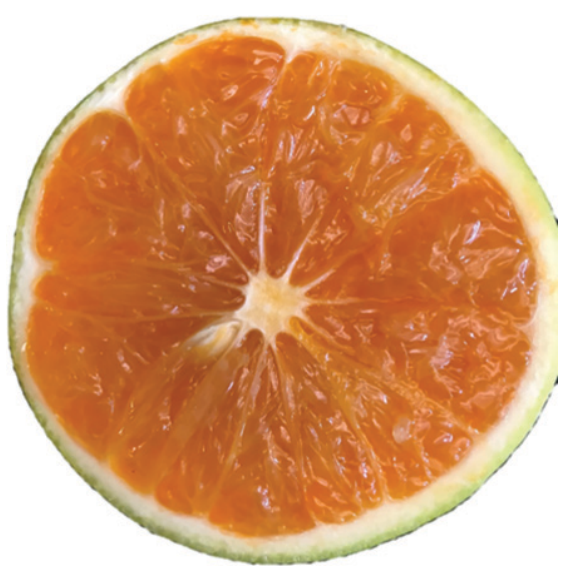

Fig. 3. Grapefruit with golden flesh color, presumably a natural mutant from a seedy, white grapefruit resembling 'Duncan'.

Mutations have also resulted in the development of several patented cultivars. The advantage of clonally propagated cultivated citrus is the maintenance of desirable mutations. Horticultural traits of mutant cultivars are often lost in the zygotic seedling progeny resulting from sexual reproduction. Figure 4 shows details of grapefruit types produced by natural seedling variation, budsport mutation, and parentage of specific cultivars.

SPONTANEOUS BUDSPORT MUTATION. The seedy, white-fleshed 'Duncan' grapefruit is presumed to be the original source of the several seeded and seedless cultivars with various peels and flesh colors. Grapefruit budsport mutants were selected for two desirable traits: seedlessness and intense flesh pigmentation. Most cultivars have a yellow peel with a red blush; shaded fruit develops a more homogeneous red peel color without blush (Lado et al., 2015). Cold weather enhances a red peel color (E.S. Louzada, unpublished data). An exception to the red flesh color was observed in Texas where a deep golden-fleshed seedy grapefruit (Fig. 3) was found. It is presumed to have originated from a 'Duncan'-like white grapefruit because reversion to a seedy, white grapefruit was observed in some trees (E.S. Louzada, unpublished data). 'Duncan' grapefruit was initially an essential cultivar in Florida, but it was later replaced by the nearly seedless Marsh grapefruit and then by Ruby Red. Two new cultivars, Shambar and Thompson, originated from Marsh grapefruit as budsports. 'Thompson' itself has branched into several commercially important pigmented cultivars by naturally occurring budsports and induced mutations (Fig. 4).

InDUCED MUTATIONS. The first documented induced mutation in plants was reported in 1927. The same year, low-alkaloid forms of sweet lupine (Lupinus albus) variants resulting from induced mutations were selected, domesticated, and developed into a crop species. Since 1964, with FAO/International Atomic Energy Agency support, more than $3200 \mathrm{mu}^{-}$ tant cultivars derived from over 210 plant species have been released (Shu et al., 2011).

Technologies inducing mutations have successfully produced improved commercial grapefruit cultivars with red flesh. 'Star Ruby', produced from 'Hudson', was the first successful cultivar produced by irradiation with thermal neutrons (Hensz, 1971). Interestingly, in Texas where 'Star Ruby' was developed, it did not gain commercial importance. 'Star Ruby' is a highly valued commodity in South Africa, Australia, Israel, Turkey, Spain, and Cyprus (Da Graça et al., 2004). Hensz irradiated 'Ruby Red' grapefruit with thermal neutrons, producing fruit with about three times the red color intensity of the original 'Ruby Red' and thus designated this as 'A\&I-1-48'. A budsport mutant of 'A\&I-1-48' produced fruit with flesh five times as red as 'Ruby Red'. The new cultivar was named Rio Red, currently the most important commercial grapefruit in Texas (Hensz, 1985). Recently another budsport mutation of 'Rio Red', with a homogeneous deep red peel and flesh with reduced bitterness, was discovered and patented as TR-1 (Louzada and Del Rio, 2020). A seedless version of the deep-golden-fleshed grapefruit was produced by irradiation with gamma rays at 50 Gy (E.S. Louzada, unpublished data) (Fig. 3). In South Africa, the 'RedHeart' grapefruit, formerly called 'Flamingo', was developed through induced mutations of the 'Henderson' grapefruit, and it is reported to have a lower naringin content (Citrogold, 2020) (Fig. 4).

SECTORED GRAPEFRUIT CHIMERA. A chimera is composed of cells from more than one genetically distinct organism. The first report of a chimera was described in the 1600s as a shoot emerging from a graft junction of a bitter orange (Citrus $\times$ aurantium) and a citron (Frank and Chitwood, 2016). The occurrence of sectorial chimeras has been studied in several cultivars of sweet orange, grapefruit, tangelo, and tangor (C. reticulata $\times$ C. sinensis). Chimera incidence ranges from $0.009 \%$ to $0.271 \%$ in citrus. Cultivation of progeny seedlings from fully developed or under-developed seeds derived from the chimeric fruit may be valuable for selecting cultivars with improved fruit flesh and peel color, maturity, reduced pest, and disease resistance (Bowman et al., 1991). E.S. Louzada (unpublished data) recovered grapefruit plants producing fruit with improved peel and flesh color from a grapefruit sectorial chimera (Fig. 6) now being evaluated for horticultural performance.

\section{Role of biotechnology}

SOMATIC HYBRIDIZATION AND CYBRIDIZATION. Biotechnology has been instrumental in developing novel cultivars of crop plants. In citrus, protoplast fusion was used successfully to develop new tetraploid breeding lines for rootstock development and for breeding seedless triploid forms using a tetraploid parental line in interploid crosses (Grosser et al., 1996, 1998; Guo et al., 2000; Ohgawara et al., 1989). Cybrids are produced by fusing only the cytoplasm of the two selected cultivars; potentially, 
A

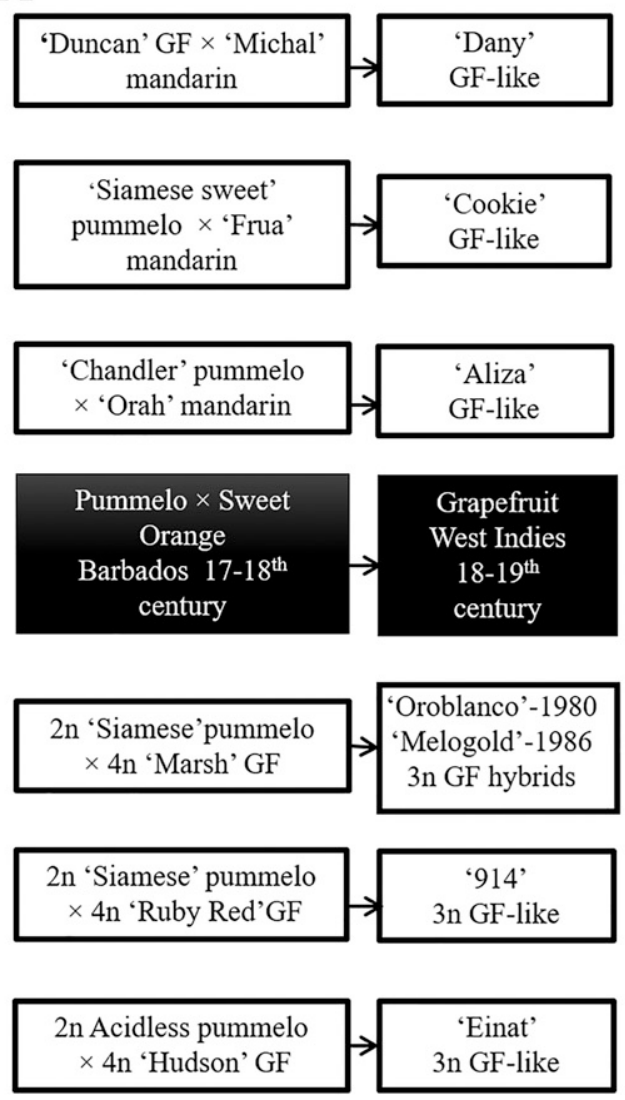

$\mathrm{B}$

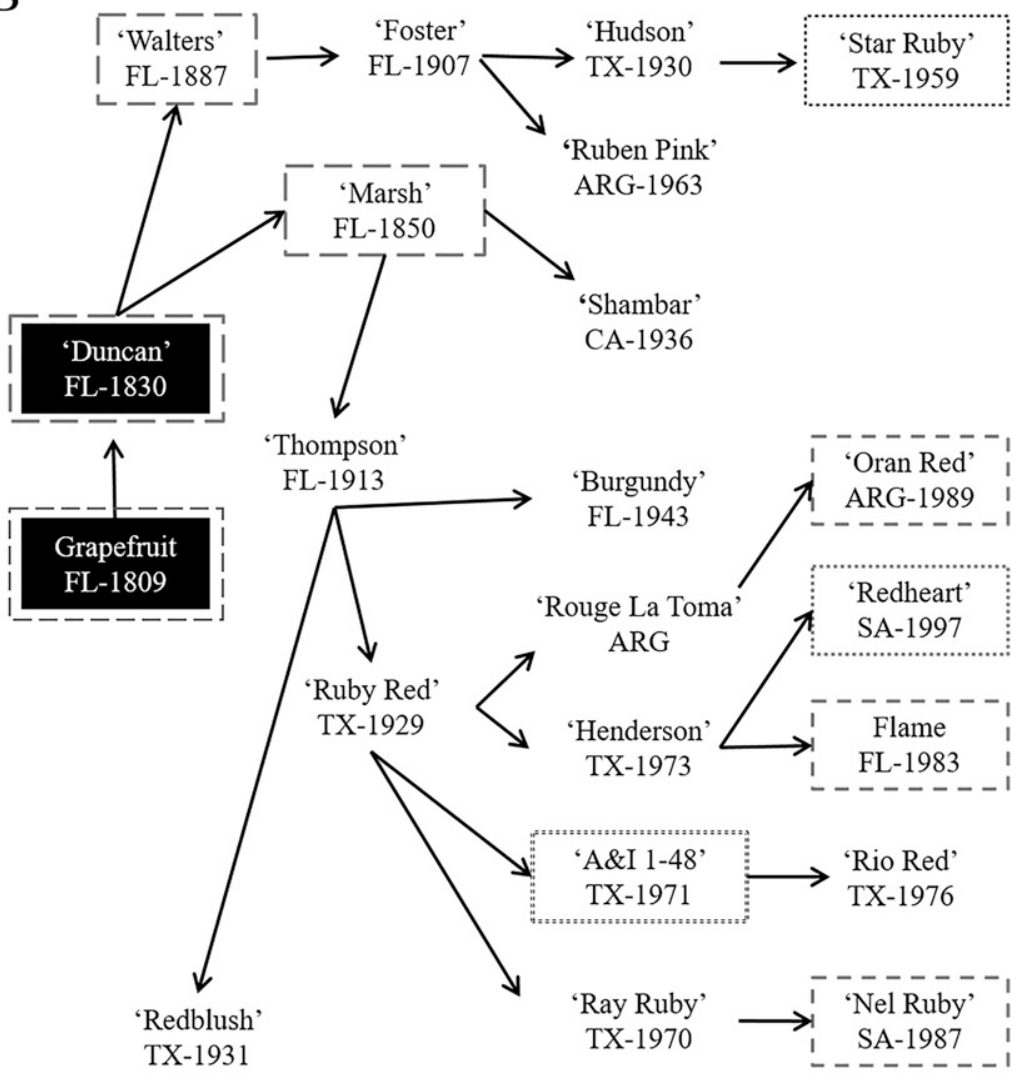

Fig. 4. Origin of major grapefruit (GF) cultivars. (A) Cultivars developed by sexual hybridization. Parentage of selected hybrids is shown. (B) Cultivars resulting from spontaneous or induced mutations. Major events involved in GF origin are shown in black rectangles. Names of budsport cultivars are shown without borders. Dotted rectangles represent cultivars arising through irradiations. Seedling-derived cultivars are shown in boxes with dashes. Year and place of cultivar development are indicated: Florida (FL), Texas (TX), California (CA), South Africa (SA), and Argentina (ARG). Modified from Da Graça et al. (2004).

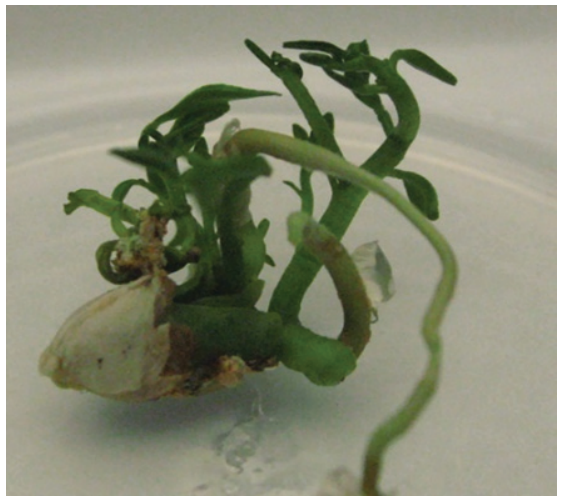

Fig. 5. Germinated seed of 'Rio Red' grapefruit demonstrating the presence of various embryos in a single seed (polyembryony).

unique hybrids with horticulturally interesting combinations can be developed. Omar et al. (2017) reported the production of grapefruit cybrids with putative citrus canker resistance by fusion of the mesophyll protoplast from three different grapefruit cultivars with the protoplast from embryogenic suspension cells of the citrus canker-resistant 'Meiwa' kumquat (Fortunella $\times$ crassifolia). Satpute et al. (2015) reported somatic hybridization of 'Dancy' mandarin suspension cells with haploid 'Ruby Red' grapefruit and obtained one triploid hybrid and several cybrids resembling grapefruit. The fusion of 'Dancy' mandarin with 'Duncan' grapefruit generated grapefruit cybrids with fruit that maintain high concentrations of soluble solids during the summer season; an improvement over normal 'Duncan' that loses fruit quality and has untimely seed germination (vivipary). Somatic triploid grapefruit hybrids with normal fruit morphology were produced by electrofusion of the diploid 'Shogun' mandarin with a diploid grapefruit (Kunitake et al., 2002).

Genetic ENGINEering. Success in plant genetic engineering depends on a successful Agrobacterium tumefaciens infection for genetic transformation, and the ability to efficiently regenerate plants through tissue culture. Genetic transformation has been accomplished in most of the citrus species, including grapefruit (Moreira-Dias et al., 2000; Niedz et al., 2015; Peña et al., 2004). Grapefruit epicotyl explant is the tissue of choice for biolistic, direct introduction, and $A$. tumefaciens-mediated transformation (Wu et al., 2016). A comprehensive study of the experimental parameters that influence the regeneration efficiency of citrus rootstocks and scions is available (Niedz et al., 2015).

Disease resistance, seedlessness, and flesh pigmentation are probably the three most important horticultural 


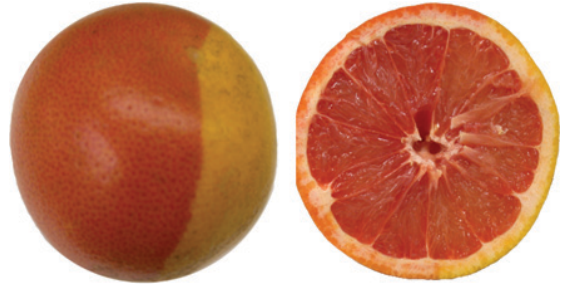

Fig. 6. A grapefruit sectored chimera found in Texas showing changes in rind and flesh coloration.

target traits for improvement of all citrus cultivars. Grapefruit is susceptible to several diseases, including quick decline caused by Citrus tristeza virus (CTV), citrus canker, and HLB. In a controlled greenhouse study of representative citrus cultivars exposed to psyllid vectors carrying the HLB pathogen, grapefruit cultivars were among the most susceptible (McCollum et al., 2016). As discussed earlier, in the United States, the Florida grapefruit industry recently declined due to citrus canker and HLB (USDA, 2019). The development of resistance to HLB, citrus canker, and other diseases is probably one of the most desired outcomes of a grapefruit genetic improvement program. Even though commercial transgenic citrus cultivars are not yet developed, several successful genetic transformation reports of grapefruit are available. Luth and Moore conducted the first transformation of grapefruit using epicotyl segments (Luth and Moore, 1999; Moore et al., 2000). Yang et al. (2000) generated transgenic 'Rio Red' grapefruit plants expressing a CTV coat protein gene and an antiviral agglutinin gene from the snowdrop plant (Galanthus nivalis). Febres et al. (2003) transformed 'Duncan' grapefruit with genomic segments from CTV to obtain transgenic plants with resistance. Among several transgenic plants transformed with the coat protein gene from different CTV strains, one plant was resistant, six were partially resistant, and 27 were susceptible to the virus (Febres et al., 2007). Çevic et al. (2012) reported the production of transgenic 'Duncan' grapefruit expressing the wild-type and mutant RNA-dependent RNA polymerase genes of CTV; the disease resistance status of the transgenic plants has not been reported. CTV has several intra and intercellular silencing suppressors that affect host resistance and facilitate viral colonization. Calvo (2013) targeted these suppressors with small interfering RNA and obtained transgenic plants resistant to the virus; however, the resistance was compromised when CTV strains with divergent suppressors were used to challenge the transgenic plants. Several groups are now conducting research to produce transgenic citrus resistant to HLB and citrus canker, two of the most economically significant citrus diseases. Grosser et al. (2011) produced several transgenic plants of sweet orange, grapefruit, lime (Citrus $\times$ aurantiifolia), and 'Carrizo' citrange $[(C . \times$ aurantium $) \times$ C. trifoliata] expressing antimicrobial peptides. Selected plants showed significantly higher resistance to citrus canker compared with untransformed controls in detached leaf assays. E.S. Louzada (unpublished data) produced transgenic 'Valencia' and 'Hamlin' sweet oranges and 'Ruby Red' grapefruit expressing a gene responsible for enhanced calcium signals; the transgenic plants showed strong resistance to root rot caused by P. nicotianae and citrus canker. Evaluation for HLB resistance is in progress. In studies conducted to understand cytokinin's role in conferring resistance to pathogens, Pasquali et al. (2009) transformed grapefruit with an isopentenyltransferase $(i p t)$ gene known to increase cytokinin levels. The expression of $i p t$ was driven by a floral promoter. The transformed plants had 30\% higher chlorophyll content in the fully expanded uppermost leaves compared with control plants. A 9- to 32-fold increase in endogenous concentration of transzeatin riboside (the most active form of naturally occurring cytokinin) was observed. Significantly higher expression of specific pathogenesis-related genes was also recorded.

Novel, powerful molecular techniques are currently available for the genetic engineering of plants. As these techniques are established and perfected for citrus, and more high-quality complete genome sequences become available, there will be new opportunities for successful manipulation of the grapefruit genome.

\section{Germplasm biodiversity and molecular markers}

For over two centuries, grapefruit was presumed to be an interspecific hybrid between a pummelo and a sweet orange; recent genome sequence analyses have confirmed this assumption (Wu et al., 2018). Chloroplast genome analysis, a powerful tool to study the female parent's contribution, indicates that pummelo is the seed parent and sweet orange is the pollen parent of grapefruit. Based on molecular evidence, grapefruit is assumed to be the result of a backcross of sweet orange with pummelo (Nicolosi et al., 2000). Phylogenomic karyotypes studies clustered grapefruit in an intermediary position between pummelo and sweet orange. It was estimated that about $63 \%$ of the grapefruit genome was contributed by the pummelo parent (Oueslati et al., 2017). From the initial point of hybridization to now, the commercially significant grapefruit cultivars have maintained their homogeneous genetic identity because of apomixis. Grapefruit has a very narrow genetic base because all the important commercial cultivars originated from spontaneous budsports or induced mutations. Corazza-Nunes et al. (2002) used random amplified polymorphic DNA and simple sequence repeat markers to study the genetic variability of grapefruit cultivars. Marsh Seedless, Duncan, Thompson Pink, Foster, and Red Blush cultivars were 100\% like each other in the genomic regions included in the analysis. The only grapefruit cultivars that showed polymorphism at the nucleotide level were accessions known to be hybrids with grapefruit parentage, such as Triumph (C. aurantium), Royal grapefruit, and others. Sharma et al. (2015) studied the genetic diversity using microsatellite markers and reported that 'Star Ruby', 'Foster', and 'Duncan' were $100 \%$ similar genetically.

\section{Genetic resources: Most important cultivars}

'Duncan'. This cultivar is historically significant because most grapefruit cultivars in the market today are derived from Duncan (Fig. 7A). Although named in 1892, the mother tree was planted around 1830 (Hodgson, 1967). 'Duncan' is currently not commercially significant because the fruit is very seedy; it was replaced by the more desirable seedless cultivar Marsh (Fig. 7B) and then by the pigmented mutants. As of 2000, Florida produced about 368 tons of 'Duncan' 


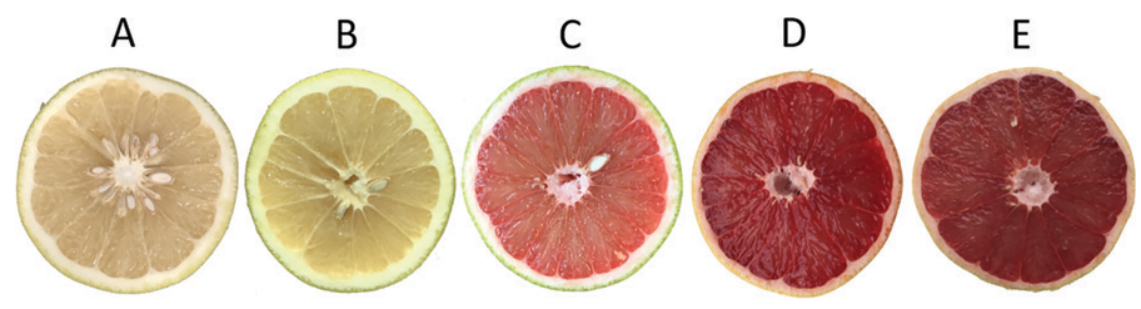

Fig. 7. Most important grapefruit cultivars derived from the white seeded Duncan, first grapefruit planted in the United States, to the dark-red Rio Red grapefruit. (A) 'Duncan', (B) 'White Marsh', (C) 'Ruby Red', (D) 'Rio Red', and (E) 'Star Ruby'.

grapefruit per year designated solely for juice processing.

'MARSH'. Also known as 'Marsh Seedless' and 'White Marsh', this cultivar was discovered in 1850 (Shamel et al., 1918), but it gained prominence after 1886. It is seedless or nearly seedless, with internal coloration ranging from pale- to light-yellow at maturity (Fig. 7B) (Hodgson, 1967). 'Marsh' is still considered important in most grapefruit-producing countries; horticulturally superior cultivars with pigmented flesh have now replaced the white-fleshed types (Saunt, 2000).

'Ruby ReD'. A budsport mutation from 'Thompson' was discovered in Texas in 1929 and patented in 1934. It became a significant commercial cultivar worldwide wherever grapefruit was cultivated (Saunt, 2000). 'Ruby Red' is the premier cultivar in Florida, with about 25,700 acres of bearing trees as of 2016 (USDA, 2017a). The fruit has very few seeds; the flesh has more pigmentation than 'Thompson', and the peel has a reddish blush. The internal fruit quality is like 'Marsh' except for pigmentation pattern (Saunt, 2000) (Fig. 7C). 'Redblush' grapefruit also originated as a natural mutant from 'Thompson' in 1929, but it did not attain the popularity of 'Ruby Red'.

'Ruo RED'. Originating as a budsport mutant from 'A\&I-1-48', it is a grapefruit cultivar produced in Texas by irradiation of Ruby Red budwood with thermal neutrons. 'Rio Red' (Fig. 7D) has a yellow peel with various degrees of reddish color developing when fruit are shaded inside the canopy. The flesh is deep red but lighter than 'Star Ruby', with flesh color fading later in the season. The fruit tends to sheep-nose, developing a depressed button resulting in a snout-like appearance (Patil, 2001). This cultivar is important in Texas; it is also planted in Arizona, California, and Mexico. Small plantings are reported in Argentina, Israel, Turkey, South Africa, and Spain (Da Graça et al., 2004).

'STAR RUBY'. It originated through irradiation of 'Hudson' grapefruit of seeds with thermal neutrons. This cultivar was released in Texas during 1970. The fruit peel is yellow with a slight tendency to red coloration and a clear red blush. The flesh color is deep red, with more than three times the pigmentation of 'Ruby Red' (Hensz, 1971) (Fig. 7E). Problems with alternate bearing, sunscald, micronutrient deficiencies, and herbicides damage reduced cultivar Star Ruby's value in Texas. 'Star Ruby' is currently commercially important in South Africa, Israel, Australia, Cyprus, and Turkey (Da Graça et al., 2004).

'Flame'. This cultivar is a seedling tree derived from Henderson grapefruit, found in Texas, and released in 1987. Fruit is round with a good appearance, the fruit rind is thin with a red-bronze blush, and the flesh coloration is red, similar to 'Rio Red'. 'Flame' became important in Argentina and Florida.

'TR-1'. A new spontaneous mutant derived from 'Rio Red' grapefruit was discovered in Texas and patented in 2020 (Louzada and Del Rio, 2020). The rind and flesh are very red, and the flavor is mild with reduced bitterness. The trees of 'TR-l' tend to produce numerous fruit clusters inside the canopy (Figs. 8 and 9). Release for commercial planting is expected by 2022 .

\section{Conclusions and prospects}

Grapefruit is the youngest member of the citrus species; it has an intriguing, almost romantic history, its unique origin shrouded in mystery. It is considered a superior citrus fruit

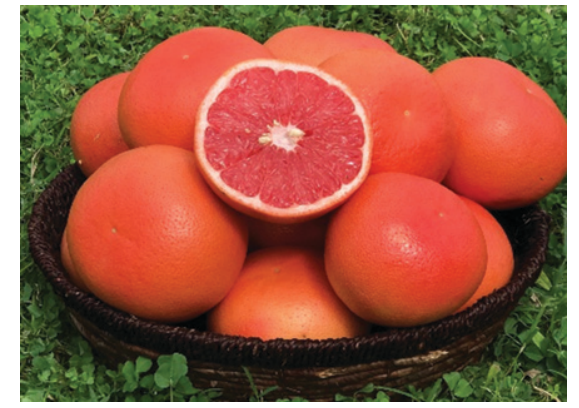

Fig. 8. Grapefruit cultivar TR-1, a natural mutant of Rio Red, showing external and internal coloration.

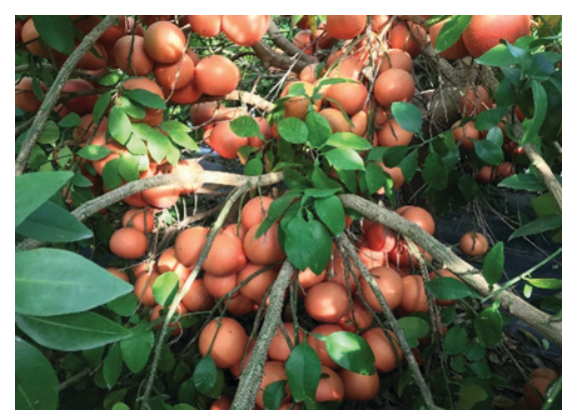

Fig. 9. A 5-year-old tree of 'TR-1' grapefruit showing fruit production inside the canopy. The rootstock was 'C-22' (Poncirus trifoliata $\times$ Citrus sunki).

because of its nutritional value and the numerous medicinal properties attributed to phytochemicals. Although grapefruit is less than 300 years in age, an extensive range of cultivars with different peel and flesh colors are now available; most of these originated through natural or induced mutations. Molecular marker studies with grapefruit cultivars indicate a high degree of genetic similarity despite the morphological and horticultural differences discernible among cultivars. Because the somatic mutations cause observable diversity in genetically similar cultivars, grapefruit is considered a monocrop. The use of grapefruit as a seed parent in conventional breeding is challenging because of its complex biology; the polyembryony trait limits the production of the hybrid progeny required to select superior cultivars. Biotechnology has been instrumental in producing grapefruit cybrids and tetraploid somatic hybrids that are useful for producing commercially valuable triploid cultivars by interploid crosses. Because genetic transformation techniques are well developed for 
grapefruit systems, candidate genes putatively associated with valuable traits can be used to transform established cultivars. New molecular techniques that are now developed will expand the opportunities for creating unique cultivars by genome editing and by precision genetic engineering. Clustered regularly interspaced short palindromic repeats (CRISPR) is currently a promising molecular technique that will allow for precise editing of existing genes. Specific modification of target genes can generate horticulturally superior forms with valued traits. Currently, genetic variants generated by CRISPR technology are not considered as genetically modified organisms and hence not regulated as such. This scenario opens novel opportunities for generating superior cultivars using new technologies.

Interaction of the furanocoumarins present in grapefruit with the metabolism of several prescription drugs in the human system is of concern. It is possible to alleviate some problems with improved juice-processing techniques and development of cultivars with lower concentrations of interfering compounds. Considering the health benefits associated with grapefruit consumption, such studies will prove valuable. From a commercial perspective, the future appears promising as novel opportunities arise when grapefruit cultivation becomes feasible in new production areas.

\section{Literature cited}

Agca, C.A., M. Tuzcu, H. Gencoglu, F. Akdemir, S. Ali, K. Sahin, and O. Kucuk. 2012. Lycopene counteracts the hepatic response to 7,12 -dimethylbenz $[\alpha]$ anthracene by altering the expression of $\mathrm{Bax}, \mathrm{Bcl}-2$, caspases, and oxidative stress biomarkers. Pharm. Biol. 50:1513-1518, doi: 10.3109/ 13880209.2012.688057.

Agosti, S., L. Casalino, G. Bertero, A. Barsotti, C. Brunelli, and S. Morelloni. 2012. A dangerous fruit juice. Amer. J. Emerg. Med. 30:248.e5-248.e8, doi: 10.1016/j.ajem.2010.08.031.

Ardawi, M.M., M.H. Badawoud, S.M. Hassan, A.A. Rouzi, J.M.S. Ardawi, N.M. AlNosani, M.H. Qari, and S.A. Mousa. 2016. Lycopene treatment against loss of bone mass, microarchitecture and strength in relation to regulatory mechanisms in a postmenopausal osteoporosis model. Bone 83:127-140, doi: 10.1016/ j.bone.2015.10.017.

Bailey, D.G. and G.K. Dresser. 2012. Interactions between grapefruit juice and cardiovascular drugs. Amer. J. Cardiovasc. Drugs 4:281-297, doi: 10.2165/ 00129784-200404050-00002.

Bailey, D.G., J.D. Spence, B. Edgar, C.D. Bailiff, and J.M. Arnold. 1989. Ethanol enhances the hemodynamic effects of felodipine. Clin. Invest. Med. 12:357-362

Bailey, D.G., G. Dresser, and J.M. Arnold. 2013. Grapefruit-medication interactions: Forbidden fruit or avoidable consequences? Can. Med. Assoc. J. 185:309-316, doi: $10.1503 / \mathrm{cmaj} .120951$.

Benavente-Garcia, O., J. Castillo, F.R. Marin, A. Ortuno, and J.A. Del Rio. 1997. Uses and properties of citrus flavonoids. J. Agr. Food Chem. 45:45054515, doi: 10.1021/jf970373s.

Bharadwaj, M. and A. Kumar. 2016. Neuroprotective effect of lycopene against PTZ-induced kindling seizures in mice: Possible behavioural, biochemical and mitochondrial dysfunction. Phytother. Res. 30:306-313, doi: 10.1002/ptr.5533.

Bowman, K.D. and F.G. Gmitter, Jr. 1990. Forbidden fruit (Citrus sp., Rutaceae) rediscovered in Saint Lucia. Econ. Bot. 44:165173, doi: 10.1007/BF02860484.

Bowman, K.D., F.G. Gmitter, Jr., G.A. Moore, and R.L. Rouseff. 1991. Citrus fruit sector chimeras as a genetic resource for cultivar improvement. J. Amer. Soc. Hort. Sci. 116:888-893, doi: 10.21273/ JASHS.116.5.888.

Bressier, R. and J.J. Bahl. 2003. Principles of drug therapy for the elderly patient. Mayo Clin. Proc. 78:1564-1577, doi: 10.4065/78.12.1564.

Browne, P. 1756. The civil and natural history of Jamaica: In three parts. P. Browne, London, UK, doi: 10.5962/ bhl.title.10826.

Burton-Freeman, B.M. and H.D. Sesso. 2014. Whole food versus supplement: Comparing the clinical evidence of tomato intake and lycopene supplementation on cardiovascular risk factors. Adv. Nutr. 5: 457-485, doi: 10.3945/an.114.005231.

Calvo, N.S. 2013. Transgenic resistance against Citrus tristeza virus (CTV) and analysis of the viral $\mathrm{p} 23$ protein as pathogenicity determinant in citrus. M.S. Thesis, Polytechnic Univ. Valencia, Valencian Inst. Agric. Res., Valencia, Spain, doi: 10.4995/Thesis/10251/31631.

Cameron, J.W., R.K. Soost, and E.O. Olson. 1964. Chimeral basis for color in pink and red grapefruit. J. Hered. 55:23-28, doi: 10.1093/oxfordjournals.jhered.al07279.

Cancalon, P.F., S.M. Barros, C. Haun, and W.M.Widmer. 2011 . Effect of maturity, processing, and storage on the furanocoumarin composition of grapefruit and grapefruit juice. J. Food Sci. 76:C543-C548, doi: 10.1111/j.1750-3841.2011.02147.x.

Caseiro, M., A. Ascenso, A. Costa, J. Creagh-Flynn, M. Johnson, and S. Simões. 2020. Lycopene in human health. LWT Food Sci. Technol. 127:109323, doi: 10.1016/j.lwt.2020.109323.

Cevic, B., R.F. Lee, and C.L. Niblett. 2012. Agrobacterium-mediated transformation of grapefruit with the wild-type and mutant RNA-dependent RNA polymerase genes of Citrus tristeza virus. Turk. J. Agr. For. 36:195-206, doi: 10.3906/ tar-1008-1192.

Chen, W., L. Mao, H. Xing, L. Xu, X. $\mathrm{Fu}$, L. Huang, D. Huang, Z. Pu, and Q. Li. 2015. Lycopene attenuates $\mathrm{A} \beta 1-42$ secretion and its toxicity in human cell and Caenorhabditis elegans models of $\mathrm{Alz}$ heimer disease. Neurosc. Lett. 608:2833, doi: 10.1016/j.neulet.2015.10.009.

Chien, P., F. Sheu, and Y.T. Shyu. 2001. Monitoring the enzymatic de-bittering in grapefruit juice by high performance liquid chromatography. J. Food Drug Anal. 9(2):8, doi: 10.38212/2224-6614.2802.

Chudnovskiy, R., A. Thompson, K. Tharp, M. Hellerstein, J.L. Napoli, and A. Stahl. 2014. Consumption of clarified grapefruit juice ameliorates high-fat diet induced insulin resistance and weight gain in mice. PLoS One 9(10):e108408, doi: 10.1371/journal.pone.0108408.

Citrogold. 2020. Redheart grapefruit (formerly known as Flamingo 17). 7 Oct. 2020. <https://www.citrogold.co.za/assets/ citrogold-redheart-grapefruit-formerlyflamingo-17-07.2016.pdf $>$.

Citrus Industry News. 2020. The first CLaspositive ACP found in California grove. 7 Aug. 2020. <http://citrusindustry.net/ 2020/08/07/first-clas-positive-acp-found-incalifornia-grove $/>$.

Civerolo, E. 2015. ACP and HLB detection in California. Citrograph Mag. 2015 (Winter):8-9. 19 Aug. 2020. <https:// swfrec.ifas.ufl.edu/hlb/database/pdf/ 12_Civerolo_15.pdf $>$.

Codoñer-Franch, P. and V. Valls-Belles. 2010. Citrus as functional foods. Curr. Top. Nutraceutical Res. 8(4):173-184.

Corazza-Nunes, M.J., M.A. Machado, W.M.C. Nunes, M. Cristofani, and M.L.P.N. Targon. 2002. Assessment of genetic variability in grapefruits (Citrus paradisi Macf.) and pummelos (C. maxima (Burm.) Merr.) using RAPD and SSR markers. Euphytica 126:169-176, doi: 10.1023/A:1016332030738.

Curl, A.L. and G.F. Bailey. 2006. The carotenoids of Ruby Red grapefruit. J. 
Food Sci. 22:63-68, doi: 10.1111/ j.1365-2621.1957.tbl6983.x.

Da Graça, J.V., E.S. Louzada, and J.W. Sauls. 2004. The origin of red-pigmented grapefruit and the development of new varieties. Proc. Inter. Soc. Citricult. 1: 369-374.

Da Silva, R.R., T.T. de Oliveira, T.J. Nagem, A.S. Pinto, L.F. Albino, M.R de Almeida, G.H. de Moraes, and J.G. Pinto. 2001. Hypocholesterolemic effect of naringin and rutin flavonoids. Arch. Latinoam. Nutr. 51: 258-264.

DePass, J.P. 1890. The present condition and treatment of orange groves. State Agr. College Exp. Stn. Florida Bull. 10:223-227.

Dreier, J.P. and M. Endres. 2004. Statinassociated rhabdomyolysis triggered by grapefruit consumption. Neurology 62: 670doi: 10.1212/wnl.62.4.670.

Dresser, G.K., D.G. Bailey, and S.G. Carruthers. 2000. Grapefruit juice-felodipine interaction in the elderly. Clin. Pharmacol. Ther. 68:28-34, doi: 10.1067/ mcp.2000.107524.

Ducharme, M.P., L.H. Warbasse, and D.J. Edwards. 1995. Disposition of intravenous and oral cyclosporine after administration with grapefruit juice. Clin. Pharmacol. Ther. 57:485-491, doi: 10.1016/0009-9236(95)90032-2.

Febres, V.J., C.L. Niblett, R.F. Lee, and G.A. Moore. 2003. Characterization of grapefruit plants (Citrus paradisi Macf.) transformed with the citrus tristeza closterovirus genes. Plant Cell Rep. 21:421428, doi: 10.1007/s00299-002-0528-y.

Febres, V.J., R.F. Lee, and G.A. Moore. 2007. Transgenic resistance to Citrus tristeza virus in grapefruit. Plant Cell Rep. 27:93-104, doi: 10.1007/s00299-0070445-1.

Fidel, L., M. Carmeli-Weissberg, Y. Yaniv, F. Shaya, N. Dai, E. Raveh, Y. Eyal, R. Porat, and N. Carmi. 2016. Breeding and analysis of two new grapefruit-like varieties with low furanocoumarin content. Food Nutr. Sci. 7: 90-101, doi: 10.4236/fns.2016.72011.

Frank, M.H. and D.H. Chitwood. 2016. Plant chimeras: The good, the bad, and the 'Bizzaria'. Dev. Biol. 419:41-53, doi: 10.1016/j.ydbio.2016.07.003.

Freie, R.L. 1987. Citrus summary. 6 Nov. 2019. <https://www.nass.usda.gov/ Statistics_by_State/Florida/Publications / Historical_Summaries/citrus/cs/citrus\% 20summary-1985-1986.pdf.

Garg, S.K., N. Kumar, V.K. Bhargava, and S.K. Prabhakar. 1998. Effect of grapefruit juice on carbamazepine bioavailability in patients with epilepsy. Clin.
Pharmacol. Ther. 64:286-288, doi: 10.1016/S0009-9236(98)90177-1.

Giovannucci, E. 2005. Tomato products, lycopene, and prostate cancer: A review of the epidemiological literature. J. Nutr. 135:2030S-2031S, doi: 10.1093/ jn/135.8.2030S.

Girennavar, B., G.K. Jayaprakasha, and B.S. Patil. 2008. Influence of pre- and post-harvest factors and processing on the levels of furocoumarins in grapefruits (Citrus paradisi Macfed.). Food Chem. 111:387-392.

Gmitter, F.G., Jr. 1995. Origin, evolution, and breeding of the grapefruit. Plant Breed. Rev. 13:345-363, doi: 10.1002/ 97804706500 59.chl0.

Gmitter, F.G., Jr. 2014. Pummelo grapefruit hybrid tree named 914. U.S. Patent 20140283239, filed 14 Mar. 2014, issued 12 Jan. 2015.

Goenig, N. 1937. The Texas citrus situation. Texas Farm. Citricult. 13(9):4.

Grabowsky, J.A. 2013. Drug interactions and the pharmacist: Focus on everolimus. Ann. Pharmacother. 47:1055-1063, doi: 10.1345/aph.1R769.

Graham, J.H., T.R. Gottwald, J. Cubero, and D.S. Achor. 2004. Xanthomonas axonopodis pv. citri: Factors affecting successful eradication of citrus canker. Mol. Plant Pathol. 5:1-15, doi: 10.1046/j.13643703.2004.00197.x.

Grosser, J.W., F.A. Mourao-Fo, F.G. Gmitter, Jr., E.S. Louzada, J. Jiang, K. Baergen, A. Quiros, C. Cabasson, J.L. Schell, and J.L. Chandler. 1996. Allotetraploid hybrids between Citrus and seven related genera produced by somatic hybridization. Theor. Appl. Genet. 92: 577-582, doi: 10.1007/BF00224561.

Grosser, J.W., J. Jiang, F.A.A. MourãoFo, E.S. Louzada, K. Baergen, J.L. Chandler, and F.G. Gmitter, Jr. 1998. Somatic hybridization, an integral component of citrus cultivar improvement: I. Scion improvement. HortScience 33:1057-1059, doi: 10.21273/HORTSCI.33.6.1057.

Grosser, J.W., M. Dutt, A. Omar, V. Orbovic, and G. Barthe. 2011. Progress towards the development of transgenic resistance in citrus. Acta Hort. 892:101-107, doi: 10.17660/ ActaHortic.2011.892.12.

Gunasekera, R.S., K. Sewgobind, S. Desai, L. Dunn, H.S. Black, W.L. McKeehan, and B. Patil. 2007. Lycopene and lutein inhibit proliferation in rat prostate carcinoma cells. Nutr. Cancer 58:171-177, doi: 10.1080/01635580701328339.

Guo, W.W., X.X. Deng, and H.L. Yi. 2000. Somatic hybridization between
Navel orange (Citrus sinensis) and grapefruit (C. paradisi) for seedless triploid breeding. Euphytica 116:281-285, doi: 10.1023/A:1004031621777.

Gupta, S., M.K. Jawanda, V. Arora, N. Mehta, and V. Yadav. 2015. Role of lycopene in preventing oral diseases as a nonsurgical aid of treatment. Intl. J. Prev. Med. 6: 70, doi: 10.4103/2008-7802.162311.

Gupta, S.K., D. Trivedi, S. Srivastava, S. Joshi, N. Halder, and S.D. Verma. 2003. Lycopene attenuates oxidative stress induced experimental cataract development: An in vitro and in vivo study. Nutrition 19:794-799, doi: 10.1016/S08999007(03)00140-0.

Halbert, S.E. 2005. The discovery of huanglongbing in Florida. Proc. II Intl. Citrus Canker Huanglongbing Res. Wkshp., Orlando, FL, 7-11 Nov. 2005. 7 Oct. 2020. $<$ https://swfrec.ifas.ufl.edu/hlb/database/ pdf/22_CankerHuang_05.pdf $>$.

Hanley, M.J., P. Cancalon, W.W. Widmer, and D.J. Greenblatt. 2011. The effect of grapefruit juice on drug disposition. Expert Opin. Drug Metab. Toxicol. 7:267-286, doi: 10.1517/17425255.2011. 553189.

Heid, J.L. 1937. The work at citrus products station. Texas Farm. Citricult. 13:4.

Hensz, R.A. 1971. Star Ruby, a new deep-fleshed grapefruit variety with distinct tree characteristics. J. Rio Grande Valley Hort. Soc. 25:54-58.

Hensz, R.A. 1985. Rio Red, a new grapefruit with deep red color. J. Rio Grande Valley Hortic. Soc. 38:75-76.

Hermans, K., D. Stockman, and F.V. Branden. 2003. Grapefruit and tonic: A deadly combination in a patient with the long QT syndrome. Amer. J. Med. 114:511-512, doi: 10.1016/S0002-9343(03)00071-8.

Hodgson, R.W. 1967. Horticultural varieties of citrus, p. 431-588. In: W. Reuther, H.J. Webber, and L.D. Batchelor (eds.). The citrus industry. Vol. 1. Univ. California Press, Berkeley, CA.

Hughes, G. 1750. The natural history of Barbados. Book V. Printed for the author, London, UK. Reprinted in 1972 by Arno Press, New York, NY.

Humes, H.H. 1909. Citrus fruits and their culture. Orange Judd, New York, NY.

Hung, W.L., J.H. Suh, and Y. Wang. 2017. Chemistry and health effects of furanocoumarins in grapefruit. J. Food Drug Anal. 25: 71-83, doi: 10.1016/j.jfda.2016.11.008.

Indexbox Marketing Association. 2017. World: Grapefruit (inc. pomelos)-Market report. Analysis and forecast to 2020. 1 Jan. 2020. 
Jung, U.J., M.K. Lee, Y.B. Park, M.A. Kang, and M.S. Choi. 2006. Effect of citrus flavonoids on lipid metabolism and glucose regulating enzyme mRNA levels in type-2 diabetic mice. Intl. J. Biochem. Cell Biol. 38:1134-1145, doi: 10.1016/ j.biocel.2005.12.002.

Kiani, J. and S.Z. Imam. 2007. Medicinal importance of grapefruit juice and its interaction with various drugs. Nutr. J. 6: 33, doi: 10.1186/1475-2891-6-33.

Ko, J.-H., F. Arfuso, G. Sethi, and K.S. Ahn. 2018. Pharmacological utilization of bergamottin, derived from grapefruits, in cancer prevention and therapy. Intl. J. Mol. Sci. 19:4048, doi: 10.3390/ ijms19124048.

Kohlmeier, L., J.D. Kark, E. Gomez-Gracia, B.C. Martin, S.E. Steck, A.F.M. Kardinaal, J. Ringstad, M. Thamm, V. Masaev, R. Riemersma, J.M. Martin-Moreno, J.K. Huttunen, and F.J. Kok. 1997. Lycopene and myocardial infarction risk in the EURAMIC study. Amer. J. Epidemiol. 146:618-626, doi: 10.1093/oxfordjournals.aje.a009327.

Kotlunow, A.M., T. Hidaka, and S.P. Robinson. 1996. Polyembryony in Citrus: Accumulation of seed storage protein in seeds and in embryos cultured in vitro. Plant Physiol. 110:599-609, doi: 10.1104/pp.110.2.599.

Kucuk, O., F.H. Sarkar, W. Sakr, Z. Djuric, M.N. Pollak, F. Khachik, Y.W. Li, M. Banerjee, D. Grignon, J.S. Bertram, J.D. Crissman, E.J. Pontes, and D.P. Wood, Jr. 2001. Phase II randomized clinical trial of lycopene supplementation before radical prostatectomy. Cancer Epidemiol. Biom. Prev. 10:861-868.

Kumamoto, J., R.W. Scora, H.W. Lawton, and W.A. Clerx. 1987. Mystery of the forbidden fruit: Historical epilogue on the origin of the grapefruit, Citrus paradisi (Rutaceae). Econ. Bot. 41:97107. <https://www.jstor.org/stable/ $4254944>$.

Kunta, M., M. Sétamou, M. Skaria, J. Rascoe, W. Li, M. Nakhla, and J.V. da Graça. 2012. First report of citrus Huanglongbing in Texas. Phytopathology 102:\$4.66.

Kunitake, H., K. Nagasawa, K. Takami, and H. Komatsu. 2002. Molecular and cytogenetic characterization of triploid somatic hybrids between 'Shogun' mandarin and grapefruit. Plant Biotechnol. 19:345-352, doi: 10.5511/plantbiotechnology.19.345.

Lado, J., P. Cronje, B. Alquézar, A. Page, M. Manzi, A. Gómez-Cadenas, A.D. Stead, L. Zacarías, and M.J. Rodrigo. 2015. Fruit shading enhances peel color, carotenes accumulation and chromoplast differentiation in red grapefruit. Physiol. Plant. 154:469484, doi: $10.1111 /$ ppl.12332.
Lee, J.W., J.K. Morris, and N.J. Wald. 2016. Grapefruit juice and statins. Amer. J. Med. 129:26-29, doi: 10.1016/ j.amjmed.2015.07.036.

Li, H., B. Yang, J. Huang, T. Xiang, X. Yin, J. Wan, F. Luo, L. Zhang, H. Li, and G. Ren. 2013. Naringin inhibits growth potential of human triple-negative breast cancer cells by targeting $\beta$-catenin signaling pathway. Toxicol. Lett. 220:219-228, doi: 10.1016/j.toxlet.2013.05.006.

Libersa, C.C., S.A. Brique, K.B. Motte, J.F. Caron, L.M. Guédon-Moreau, L. Humbert, A. Vincent, P. Devos, and M.A. Lhermitte. 2000. Dramatic inhibition of amiodarone metabolism induced by grapefruit juice. Brit. J. Clin. Pharmacol. 49:373-378, doi: 10.1046/j.13652125.2000.00163.x.

Lilja, J.J., K.T. Kivistö, J.T. Backman, T.S. Lamberg, and P.J. Neuvonen. 1998a. Grapefruit juice substantially increases plasma concentrations of buspirone. Clin. Pharmacol. Ther. 64:655-660, doi: 10.1016/S0009-9236(98)90056-X.

Lilja, J.J., K.T. Kivistö, and P.J. Neuvonen. 1998b. Grapefruit juice-simvastatin interaction: Effect on serum concentration of simvastatin, simvastatin acid, and HMG-Co A reductase inhibitors. Clin. Pharmacol. Ther. 64:477-483, doi: 10.1016/s0009-9236(98)90130-8.

Liu, R.H. 2004. Potential synergy of phytochemicals in cancer prevention: Mechanism of action. J. Nutr. 134:3479S3485S, doi: 10.1093/jn/134.12.3479S.

Louzada, E.S. and H.S. Del Rio. 2020. Grapefruit tree named 'TR-1'. U.S. Plant Patent. US PP 31,702 P3, filed 26 Jan. 2018, issued 28 Apr. 2020. 2 Dec. 2020.

Luth, D. and G. Moore. 1999. Transgenic grapefruit plants obtained by Agrobacterium tumefaciens-mediated transformation. Plant Cell Tissue Organ Cult. 57:219-222, doi: 10.1023/A:1006387900496.

Macfadyen, J. 1830. Some remarks on the species of the genus Citrus which are cultivated in Jamaica. Bot. Misc. 1:295-304. 6 Jan. 2020.

Madrigal-Bujaidar, E., L.M. Roaro, K. Garcia-Aguirre, S. Garcia-Medina, and I. Alvarez-Gonzalez. 2013. Grapefruit juice suppresses azoxymethane-induced colon aberrant crypt formation and induces antioxidant capacity in mice. Asian Pac. J. Cancer Prev. 14:6851-6856, doi: 10.7314/apjcp.2013.14.11.6851.

Mahgoub, A.A. 2002. Grapefruit juice potentiates the anti-inflammatory effects of diclofenac on the carrageenan-induced rat's paw oedema. Pharmacol. Res. 45:14, doi: 10.1006/phrs. 2001.0856.
McCollum, G., M. Hilf, M. Irey, W. Luo, and T. Gottwald. 2016. Susceptibility of sixteen citrus genotypes to 'Candidatus Liberibacter asiaticus'. Plant Dis. 100: 1080-1086, doi: 10. 1094/PDIS-08-150940-RE.

McLeaish, R.B. 1939. Citrus output and red ink. Texas Farm. Citricult. 17:8-9.

Merrill, E.D. and H.A. Lee. 1924. A consideration of the species Citrus maxima (Burm.). Merrill. Amer. J. Bot. 11:382-384.

Mertens-Talcott, S.U., I. Zadezensky, W.V. De Castro, H. Derendorf, and V. Butterweck. 2006. Grapefruit-drug interaction: Can interaction with drugs be avoided? J. Clin. Pharmacol. 46:13901416, doi: 10.1177/0091270006294277.

Mink, P.J., C.G. Scrafford, L.M. Barraj, L. Harnack, C.P. Hong, J.A. Nettleton, and D.R. Jacobs, Jr. 2007. Flavonoid intake and cardiovascular disease mortality: A prospective study in postmenopausal women. Amer. J. Clin. Nutr. 85:895909, doi: 10.1093/ajcn/85.3.895.

Monroe, K.R., F.Z. Stanczyk, K.H. Besinque, and M.C. Pike. 2013. The effect of grapefruit intake on endogenous serum estrogen levels in postmenopausal women. Nutr. Cancer 65:644-652, doi: 10.1080/ 01635581.2013.795982.

Moore, G.A., V.J. Febres, C.L. Niblett, D. Luth, M. McCaffery, and S.M. Garnsey. 2000. Agrobacterium-mediated transformation of grapefruit (Citrus paradisi Macf.) with genes from Citrus tristeza virus. Acta Hort. 535:237-244, doi: 10.17660/ActaHortic.2000.535.29.

Moreira-Dias, J.M., R.V. Molina, Y. Bordón, J.L. Guardiola, and A. GarcíaLuís. 2000. Direct and indirect shoot organogenic pathways in epicotyl cuttings of Troyer citrange differ in hormone requirements and in their response to light. Ann. Bot. 85:103-110, doi: 10.1006/anbo. 2000.1001.

Mozos, I., D. Stoian, A. Caraba, C. Malainer, J.O. Horbańczuk, and A.G. Atanasov. 2018. Lycopene and vascular health. Front. Pharmacol. 9:521, doi: 10.3389/ fphar.2018.00521.

Nature Biotechnology. 2013. Drug-proof grapefruit. Nature Biotechnol. 31:186, doi:10.1038/nbt0313-186b.

Nicolosi, E., Z.N. Deng, A. Gentile, S. La Malfa, G. Continella, and E. Tribulato. 2000. Citrus phylogeny and genetic origin of important species as investigated by molecular markers. Theor. Appl. Genet. 100: 1155-1166, doi: 10.1007/s001220051419.

Niedz, R.P., J.P. Albano, and M. Marutani-Hert. 2015. Effect of various factors on shoot regeneration from citrus epicotyl 
explants. J. Appl. Hort. 17:121-128, doi: 10.37855/jah. 2015.v17 i02.24.

Nutrition Data. 2020. Grapefruit, raw, pink and red, all areas. 2 Sept. 2020. $<$ https://nutritiondata.self.com/facts/ fruits-and-fruit-juices $/ 1905 / 2>$.

Obenland, D., S. Campisi-Pinto, and M.L. Arpaia. 2018. Determinants of sensory acceptability in grapefruit. Scientia Hort. 231:151-157, doi: 10.1016/ j.scienta.2017.12.026

Ohgawara, T., S. Kobayashi, S. Ishii, K. Yoshinaga, and I. Oiyama. 1989. Somatic hybridization in Citrus: Navel orange (C. sinensis $\mathrm{Osb}$.) and grapefruit (C. paradisi Macf.). Theor. Appl. Genet. 78:609-612, doi: 10.1007/BF00262553.

Omar, A.A., M. Murata, Q. Yu, F.G. Gmitter, Jr., C.D. Chase, J.H. Graham, and J.W. Grosser. 2017. Production of three new grapefruit cybrids with potential for improved citrus canker resistance. In Vitro Cell. Dev. Biol. 53:256-269, doi: 10.1007/s11627-017-9816-7.

Oueslati, A., A. Salhi-Hannachi, F. Luro, H. Vignes, P. Mournet, and P. Ollitrault. 2017. Genotyping by sequencing reveals the interspecific C. maxima/C. reticulata admixture along the genomes of modern citrus varieties of mandarins, tangors, tangelos and grapefruits. PLoS One 12:e0185618, doi: 10.1371/journal.pone.0185618.

Owira, P.M. and J.A. Ojewole. 2010. The grapefruit: An old wine in a new glass? Metabolic and cardiovascular perspectives. Cardiovasc. J. Afr. 21:280-285, doi: 10.5830/CVJA-2010-012.

Özdemir, M., Y. Aktan, B.S. Bovdaĝ, M.I. Cingi, and A. Musmul. 1998. Interaction between grapefruit juice and diazepam in humans. Eur. J. Drug Metab. Pharmacokinet. 23:55-59, doi: 10.1007/ BF03189827.

Paine, M.F., W.W. Widmer, H.L. Hart, S.N. Pusek, K.L. Beavers, A.B. Criss, S.S. Brown, B.F. Thomas, and P.B. Watkins. 2006. A furanocoumarin-free grapefruit juice establishes furanocoumarins as the selective mediators of the grapefruit juicefelodipine interaction. Amer. J. Clin. Nutr. 83:1097-1105, doi: 10.1093/ ajcn/83.5.1097

Pan, M.-H., C.-S. Lai, and C.-T. Ho. 2010. Anti-inflammatory activity of natural dietary flavonoids. Food Funct. 1:1531, doi: 10.1039/c0fo00103a.

Pasquali, G., V. Orbović, and J.W. Grosser. 2009. Transgenic grapefruit plants expressing the $\mathrm{P}_{\text {APETALA3 }}-\mathrm{IPT}_{\mathrm{gp}}$ gene exhibit altered expression of PR genes. Plant Cell Tissue Organ Cult. 97:215223, doi: 10.1007/s1 1240-009-9517-y.
Patil, B.S. 2001. Location and rootstock affect sheepnosing in grapefruit. HortScience 36:710-713, doi: 10.21273/ HORTSCI.36.4.710.

Peña, L., R.M. Pérez, M. Cervera, J.A. Juárez, and L. Navarro. 2004. Early events in Agrobacterium-mediated genetic transformation of citrus explants. Ann. Bot. 94: 67-74, doi: 10.1093/aob/mchl17.

Peynaud, D., B. Charpiat, T. Vial, M. Gallavardin, and C. Ducerf. 2007. Tacrolimus severe overdosage after intake of masked grapefruit in orange marmalade. Eur. J. Clin. Pharmacol. 63:721-722, doi: 10.1007/s00228-007-0323-3.

Powell, C. 1929. West Indian grapefruit. Valley Farmer 5(Feb):32-33.

Rampersaud, G.C. 2007. A comparison of nutrient density scores for $100 \%$ fruit juices. J. Food Sci. 72:S261-S266, doi: 10.1111/j.1750-3841.2007.00324.x.

Raveh, E., L. Goldengerg, R. Porat, N. Carmi, A. Gentile, and S. La Malfa. 2020. Conventional breeding of cultivated citrus varieties, p. 33-48. In: A. Gentile, S. La Malfa, and Z. Deng (eds.). The citrus genome. Springer, Cham, Switzerland.

Robinson, T.R. 1952. Grapefruit and pummelo. Econ. Bot. 6:228-245, doi: $10.1007 / \mathrm{BF} 02985064$.

Rothenstein, J.M. and N. Letarte. 2014. Managing treatment-related adverse events associated with Alk inhibitors. Curr. Oncol. 21:19-26, doi: 10.3747/co.21.1740.

Rouseff, R.L., S.F. Martin, and C.O. Youtsey. 1987. Quantitative survey of narirutin, naringin, hesperidin, and neohesperidin in citrus. J. Agr. Food Chem. 35: 1027-1030, doi: 10.1021/jf00078a040.

Sato, R., K.J. Helzlsouer, A.J. Alberg, S.C. Hoffman, E.P. Norkus, and G.W. Comstock. 2002. Prospective study of carotenoids, tocopherols, and retinoid concentrations and the risk of breast cancer. Cancer Epidemiol. Biomarkers Prev. $11: 451-457$.

Satpute, A.D., C. Chen, F.G. Gmitter, P. Ling, Q. Yu, M.R. Grosser, J.W. Grosser, and C.D. Chase. 2015. Cybridization of grapefruit with 'Dancy' mandarin leads to improved fruit characteristics. J. Amer. Soc. Hort. Sci. 140:427-435, doi: 10.21273/JASHS.140.5.427.

Saunt, J. 2000. Citrus varieties of the world: An illustrated guide. 2nd ed. Sinclair Intl., Norwich, England.

Scora, R.W., J. Kumamoto, R.K. Soost, and E.M. Nauer. 1982. Contribution to the origin of the grapefruit Citrus paradisi (Rutaceae). Syst. Bot. 7:170-177, doi: $10.2307 / 2418325$.
Scora, R.W. 1975. On the history and origin of citrus. Bull. Torrey Bot. Club 102: 369-375, doi: 10.2307/2484763.

Shamel, A.D., L.B. Scott, and C.S. Pomeroy. 1918. Citrus fruit improvement: A study of bud variation in the marsh grapefruit. U.S. Dept. Agr. Bull. 697.

Sharma, N., A.K. Dubey, M. Srivastav, B.P. Singh, A.K. Singh, and N.K. Singh. 2015. Assessment of genetic diversity in grapefruit (Citrus paradisi Macf) cultivars using physico-chemical parameters and microsatellite markers. Austral. J. Crop Sci. 9:62-68.

Shaw, P.E., K.L. Goodner, M.G. Moshonas, and C.J. Hearn. 2001. Comparison of grapefruit fruit with parent fruit based on composition of volatile components. Scientia Hort. 91:71-80, doi: 10.1016/ S0304-4238(01)00241-2.

Shu, Q.Y., B.P. Forster, and H. Nakagawa (eds.). 2011. Plant mutation breeding and biotechnology. Joint FAO/IAEA Division of Nuclear Techniques in Food and Agriculture, International Atomic Energy Agency, Vienna, Austria. 4 Dec. 2019. <http://www.fao. org/3/a-i2388e >.

Shuler, P.E. and E.F. Scarborough. 1963. Citrus summary. Florida Agricultural Statistics, Florida Department of Agriculture. 10 Oct. 2019. <https://www.nass.usda. gov/Statistics_by_State/Florida/Publications/Historical_Summaries/citrus/cs/ citrus\%20summary-1963.pdf $>$.

Soares, N.F.F. and J.H. Hotchkiss. 1998. Bitterness reduction in grapefruit juice through active packaging. Pack. Tech. Sci. 11:9-18, doi: 10.1002/(SICI)10991522(199802)11:1<9:AID-PTS413>3.0. C.O.;2-D.

Soost, R.K. and J.W. Cameron. 1980. Oroblanco: A new grapefruit hybrid. Calif. Agr. 34(11):16-17.

Soost, R.K. and J.W. Cameron. 1986. Melogold, a new pummelo-grapefruit hybrid. Calif. Agr. 40(1):30-31.

TexSun News. 1948. Lifting the sights on the citrus situation-Solving Florida's citrus market problems. Texas Farm. Citricult. 24(10):9, 17.

Toolapong, P., H. Komatsu, and M. Iwamasa. 1996. Triploids and haploid progenies derived from small seeds of 'Banpeiyu', a pummelo, crossed with 'Ruby Red' grapefruit. J. Jpn. Soc. Hort. Sci. 65:255260, doi: 10.2503/jjshs.65.255.

Tundis, R., M.R. Loizzo, and F. Menichini. 2014. An overview on chemical aspects and potential health benefits of limonoids and their derivatives. Crit. Rev. Food Sci. Nutr. 54:225-250, doi: 10.1080/10408398.2011.581400. 
Tutt, E.L. 1929. Grapefruit market abroad. Valley Farmer 20:3.

Uesawa, Y. and K. Mohri. 2006a. The use of heat treatment to eliminate drug interactions due to grapefruit juice. Biol. Pharm. Bull. 29:2274-2278, doi: 10.1248/bpb.29.2274.

Uesawa, Y. and K. Mohri. 2006b. UV-irradiated grapefruit juice loses pharmacokinetic interaction with nifedipine in rats. Biol. Pharm. Bull. 29:1286-1289, doi: 10.1248/bpb.29.1286.

University of Michigan. 2016. Potassium content in foods. 19 Aug. 2020. <http:// www.med.umich.edu/llibr/Nutrition/ PotassiumHandout.pdf $>$.

U.S. Department of Agriculture. 1945. Citrus fruit: Production, farm disposition, value and utilization of sales. 9 Oct. 2019. <https://books.google.com/books?id= pdFGAQAAIAAJ\&printsec $=$ frontcover $\&$ source $=$ gbs_ge_summary_r\&cad $=0 \# \mathrm{v}=$ onepage\&q\&f=false $>$.

U.S. Department of Agriculture. 1950. Citrus summary. Grapefruit: Acreage and production. 24 Aug. 2020. < https:// www.nass.usda.gov/Statistics_by_State/ Florida/Publications/Historical_Summaries / citrus/cs/florida $\% 20$ citrus $\% 20$ fruit $\% 20$ annual\%20summary-1950>.

U.S. Department of Agriculture. 1960. Citrus summary. Grapefruit: Acreage and production. 24 Aug. 2020. < https:// www.nass.usda.gov/Statistics_by_State/ Florida/Publications/Historical_Summari es/citrus/cs/florida\%20citrus\%20fruit $\%$ 20annual\%20summary-1960.pdf $>$.

U.S. Department of Agriculture. 1973. Citrus summary. Grapefruit: Bearing acreage and production by states. 24 Aug. 2020. <https://www.nass.usda.gov/ Statistics_by_State/Florida/Publications / Historical_Summaries/citrus/cs/citrus\% 20summary-1973.pdf $>$.

U.S. Department of Agriculture. 1981. Citrus summary. Grapefruit: Bearing acreage and production by states. 24 Aug. 2020. <https://www.nass.usda.gov/Statistics_ by_State/Florida/Publications/Historical_ Summaries/citrus/cs/citrus\%20summary1981.pdf $>$.

U.S. Department of Agriculture. 2000. Citrus summary. Grapefruit: Bearing acreage and production by states. 24 Aug. 2020. <https://www.nass.usda.gov/Statistics_ by_State/Florida/Publications /Citrus / Citrus_Summary/1999-00/cs9900.pdf>.

U.S. Department of Agriculture. 2017a. Citrus fruits, 2017 summary. 15 Nov. 2019. <https://downloads.usda.library. cornell.edu/usda-esmis/files/j9602060k/ v979v5390/br86b605v/CitrFrui-08-31 2017.pdf $>$.

U.S. Department of Agriculture. 2017b. Grapefruit: Bearing acreage and production by states. 24 Aug. 2020.

U.S. Department of Agriculture. 2019. Florida citrus statistics 2017-2018. 16 June 2019. <https://www.nass.usda.gov/Statistics_by_State/Florida/Publications/>.

U.S. Department of Agriculture. 2020a. Citrus fruits, 2020 Summary. 8 Sept. 2020. $<$ https://agfstorage.blob.core.windows.net/ misc/FP_com/2020/09/02/Cit.pdf $>$.

U.S. Department of Agriculture. 2020b. Citrus: World market and trade. 13 Jan. 2020. $<$ https://apps.fas.usda.gov/psdonline/ circulars/citrus.pdf $>$.

U.S. Department of Agriculture. 2020c. Grapefruit: Bearing acreage and production by states. 24 Aug. 2020. <https:// www.nass.usda.gov/Statistics_by_State/ Florida/Publications/Citrus/Citrus_Statistics/2018-19/fcs1819.pdf>.

Vaile, R.S. 1915. The outlook for the pomelos. In: State Commission of Horticulture, The month bul. IV:509-510. 10 Oct. 2019. <https://www.google.com/books/edition/ Monthly_Bulletin_of_the_Department_of_Ag/ OTjOAAAAMAAJ?hl=en\&gbpv=l\&dq= The+outlook+for+the+pomelos.+In:+State+ Commission+of+Horticulture.+the+monthly+ bulletinprintsec $=$ frontcover $>$.

Wang, Y. and L. Reuss. 2018. The health benefits of grapefruit furanocoumarins. Univ. Florida Inst. Food Agr. Sci. Ext. Publ. FSHN18-8. 14 July. 2020. $<$ http://edis.ifas.ufl.edu/fs31l > .

Watson, E.C. 1940a. Great increase in world citrus output. Texas Farm. Citcult. 17(6):2.

Watson, E.C. 1940b. Canning, a notable development. Texas Farm. Citcult. 17(3):11.

Webber, H.J. 1967. History and development of the citrus industry, p. 1-39. In: W. Reuther, H.J. Webber, and L.D. Batchelor (eds.). The citrus industry. Vol. 1. Univ. California Press, Berkeley, CA.

Wu, H., Y. Acanda, H. Jia, N. Wang, and J. Zale. 2016. Biolistic transformation of carrizo citrange (Citrus sinensis Osb. $\mathrm{x}$ Poncirus trifoliata L. Raf.). Plant Cell Rep. 35:1955-1962, doi: 10.1007/ s00299-016-2010-2.

Wu, G.A., J. Terol, V. Ibanez, A. LópezGarcía, E. Pérez-Román, C. Borredá, C. Domingo, F.R. Tadeo, J. Carbonell-Callero, R. Alonso, F. Curk, D. Du, P. Ollitrault,
M.L. Roose, J. Dopazo, F.G. Gmitter, D.S. Rokhsar, and M. Talon. 2018. Genomics of the origin and evolution of citrus. Nature 554:311-316, doi: 10.1038/nature25447.

Xu, C.-J., P.D. Fraser, W.-J. Wang, and P.M. Bramley. 2006. Differences in the carotenoid content of ordinary citrus and lycopene-accumulating mutants. J. Agr. Food Chem. 54:5474-5481, doi: $10.1021 /$ jf060702t.

Yang, Z.N., I.L. Ingelbrecht, E.S. Louzada, M. Skaria, and T.E. Mirkov. 2000. Agrobacterium-mediated transformation on the commercially important grapefruit cultivar Rio Red (Citrus paradisi Macf.). Plant Cell Rep. 119:1203-1211. <http://hdl.handle. net/1854/LU-2014470>.

Yee, G.C., D.L. Stanley, L.J. Pessa, T.D. Costa, S.E. Beltz, J. Ruiz, and D.T. Lowenthal. 1995. Effect of grapefruit juice on blood cyclosporine concentration. Lancet 345:955-956, doi: 10.1016/S0140-6736(95)90700-9.

Yin, O.Q.P., N. Gallagher, A. Li, W. Zhou, R. Harrell, and H. Schran. 2010. Effect of grapefruit juice on the pharmacokinetics of nilotinib in healthy participants. J. Clin. Pharmacol. 50:188-194, doi: 10.1177/0091270009336137.

Yu, J., L. Wang, R.L. Walzem, E.G. Miller, L.M. Pike, and B.S. Patil. 2005. Antioxidant activity of citrus limonoids, flavonoids, and coumarins. J. Agr. Food Chem. 53: 2009-2014, doi: 10.1021/jf0484632.

Zansler, M.L., T.H. Spreen, and R.P. Muraro. 2005. Florida's citrus canker eradication program (CCEP): Benefit-cost analysis. Univ. Florida Inst. Food Agr. Sci., Ext. FE531.

Zhang, J. 2007. Flavonoids in grapefruit and commercial grapefruit juices: Concentration, distribution and potential health benefits. Proc. Florida State Hortic. Soc. 120:288-294.

Zhang, F.F., N. Morioka, T. Kitamura, S. Fujii, K. Miyauchi, Y. Nakamura, K. Hisaoka-Nakashima, and Y. Nakata. 2016. Lycopene ameliorates neuropathic pain by upregulating spinal astrocytic connexin 43 expression. Life Sci. 155:116-122, doi: 10.1016/j.lfs.2016.05.021.

Zoller, H.F. 1918. Some constituents of the american grapefruit (Citrus decumana). J. Ind. Eng. Chem. 10:364-373, doi: 10.1021/ie50101a012.

Zou, Z., W. Xi, Y. Hu, C. Nie, and Z. Zhou. 2016. Antioxidant activity of citrus fruits. Food Chem. 196:885-896, doi: 10.1016/j.foodchem.2015.09.072. 